ISSN: 0213-2060

DOI: http://dx.doi.org/10.14201/shhme2015336996

\title{
REALEZA SAPIENCIAL Y MECENAZGO CULTURAL EN LOS REINOS DE LEÓN Y CASTILLA (1000-1200)
}

\author{
Sapiential Kingship and Patronage of Learning in the Kingdoms of Leon \\ and Castile (1000-1200)
}

\author{
Manuel Alejandro RODRÍGUEZ DE LA PEÑA \\ Facultad de Humanidades y CC. de la Comunicación. Universidad CEU San Pablo. P. Juan XXIII, 6. E-28040 \\ MADRID. C. e.: arodriguez@ceu.es
}

Recibido: 2015-04-06

Revisado: 2015-07-08

Aceptado: 2015-09-28

RESUMEN: En este artículo se pretende abordar la relación existente entre formulaciones propias de una teología política de la Realeza salomónica y el mecenazgo cultural, científico y artístico de los soberanos de los reinos de León y Castilla en el periodo 10001200 a partir del estudio comparativo tanto de los textos como del contexto cortesano en el que estos intelectuales áulicos se desenvolvieron. Particularmente relevantes de cara a este análisis resultan tanto la recepción de dinámicas curiales e ideas políticas ultrapirenaicas como las mutuas influencias entre los reinos cristianos peninsulares. De la visión comparativa global se extrae la consecuencia de que estamos no ante un fenómeno regional sino ante la expresión hispánica de un movimiento ideológico y cultural del conjunto del Occidente latino medieval.

Palabras clave: Realeza sapiencial; Monarquía cristiana medieval; Mecenazgo cultural regio; Cultura literaria regia; Reinos hispánicos medievales; Cultura cortesana; Intelectuales áulicos.

ABSTRACT: This article deals with the connections between the discourse of the political Theology of Solomonic kingship and the patronage of learning and the arts displayed by the 
MANUEL ALEJANDRO RODRÍGUEZ DE LA PEÑA

REALEZA SAPIENCIAL Y MECENAZGO CULTURAL EN LOS REINOS

DE LEÓN Y CASTILLA (IOOO-I 200)

rulers of Leon and Castile in the period 1000-1200. This will be accomplished through the comparative analysis of the court intellectuals and artist and their works in their curial context. Particularly relevant for this analysis are the reception of European courtly dymanics and political ideas and the mutual influences between the Spanish Christian kingdoms themselves. From this comparative view we conclude that this was not a regional development but just the local Spanish reception of a European-wide ideological and cultural movement.

Keywords: Sapiential Kingship; Medieval Christian Rulership; Royal Patronage of Learning; Royal Literacy; Medieval Spanish Kingdoms; Courtly Culture; Courtly Intellectuals.

SUMARIO: 0 Introducción. 1 Alfonso III el Magno: un precursor. 2 León en el siglo XI: Fernando I y la reina Sancha. 3 El siglo XII: ¿̨un renacimiento para León y Castilla? 4 Referencias bibliográficas.

\section{INTRODUCCIÓN}

Una de las crónicas latinas más enigmáticas e interesantes del Medievo hispano, la leonesa Historia Silense (c 1120-1150), da comienzo con una plástica exaltación en clave sapiencial de la tradición cultural neogoticista: Cum olim Yspania omni liberali doctrina ubertim floreret, ac in ea studio literarum fontem Sapientie sitientes passim operam darent ${ }^{\text {. }}$ Esta Yspania en la que las Artes Liberales y «la fuente de la Sabiduría» florecían no es otra que la España visigótica, el reino que alumbró a Isidoro de Sevilla y a Julián de Toledo, cuyas figuras inspiraron al Silense ${ }^{2}$. Este comienzo lleno de resonancia se enriquece aún más cuando el cronista añade que la invasión árabe, descrita esta como "producto de una pujanza bárbara» (barbarorum fortitudine), hizo que el estudio y la doctrina visigodas se desvanecieran y cayeran en el olvido (inundata barbarorum fortitudine, studium cum doctrina funditus evanuit $)^{3}$.

Esta espectacular apertura de la Historia Silense resulta a mi juicio enormemente interesante no solo por su singular relectura intelectualista de la Reconquista y la pérdida de Espańa, sino también por considerar tan importante la cultura y el estudio como para contraponerlos favorablemente a la fortitudo (significativamente atribuida a los «bárbaros» musulmanes), una virtud marcial por lo general mucho más apreciada en el marco de una sociedad «organizada para la guerra» como la de su tiempo ${ }^{4}$. Además, decide

1 Historia Silense, ed. Justo Pérez de Urbel y Atilano González. Madrid: Consejo Superior de Investigaciones Científicas, 1959, c. 1, p. 114.

2 En torno a las cuestiones de autoría y contexto de la redacción de la Historia Silense, vid. Henriet, Patrick. "L'Historia Silensis, chronique écrite par un moine de Sahagún. Nouveaux arguments». e-Spania, 2012, vol. 14 [en línea: http://e-spania.revues.org/21655]; y MarTIN, Georges. «La Historia legionensis (llamada silensis) como memoria identitaria de un reino y como autobiografía».e-Spania, 2012, vol. 14 [en línea: http://e-spania.revues.org/21740].

3 Historia Silense, c. 1, ibíd.

4 Sobre las connotaciones ideológicas de la dupla de virtudes-arquetipos fortitudo-sapientia, cf. CuRTius, Ernst Robert. Literatura europea y Edad Media latina. México: Fondo de Cultura Económica, 1955, vol. 1, pp. 241-242. 
situar esta cuestión en el centro de su discurso historiográfico, al considerar la decadencia del studium (¡antes que el sacerdotium!) como la principal de las secuelas de la caída de España en manos de los árabes 5 .

Por consiguiente, el Silense enmarca el ideal neogoticista de los siglos x y XI en unas coordenadas reconquistadoras completamente nuevas: las de una renovatio studii gothorum (complemento de la recuperación ovetense del ordo gothorum que se convertiría así en una translatio studii similar a la propugnada por los autores carolingios para Aquisgrán). En definitiva, estamos ante un pensamiento histórico-político sapiencialista que sitúa a la sapientia como paradigma en torno al cual se organiza su discurso histórico ${ }^{6}$.

Casi dos siglos después, hacia 1278, el franciscano Juan Gil de Zamora, formado en la corte de Alfonso el Sabio, formulaba un discurso sapiencial identitario muy parecido en su De Preconiis Hispaniae-«De la Alabanza de España»-, un pequeño speculum principis didascálico para la formación del infante don Sancho. En él, además de hacer españoles a sabios de la talla del griego Aristóteles o el persa Avicena, escribía, siguiendo la estela de San Isidoro, la siguiente laus Spaniae teñida de una potente retórica sapiencial de sabor alfonsí:

del mismo modo que la abundancia de la tierra, la longanimidad de los príncipes, la caballería de los nobles y la bondad de los santos la hicieron apetecible, también España es ilustre por la reconocida elocuencia de sus filósofos, historiadores, poetas y doctores (...). España engendró a los citados varones y a otros muchos dignos de ser alabados para que la posteridad generosa de los godos tenga a quién imitar. Tiene también, como se ha dicho, apóstoles, mártires y confesores; entre los santos, santísimos doctores, entre los doctos, doctísimos. Tiene sabios, expertos entre los expertos, soldados valientes, reconocidos como tales entre los valientes del Mundo. Cauto ha de ser el príncipe que mande sobre fuertes y sabios. Feliz y glorioso será el príncipe llamado a regir tales pueblos siempre que se deje llevar por la sabiduría y se apoye en el consejo de los suyos ${ }^{7}$.

Medio siglo antes, el arzobispo cronista de Toledo, Rodrigo Jiménez de Rada, que conocía ciertamente las teorías parisinas de la translatio studii, afirmaba en el De Rebus Hispaniae que un cierto Dicineo, en la época de Sila, había enseñado a los visigodos omnem philosophiam, demostrando así que la translatio de los conocimientos se había realizado directamente por la intermediación de los visigodos, aquellos que después se identificaron con España y le transfirieron los conocimientos filosóficos y cosmológicos adquiridos en Oriente ${ }^{8}$.

5 Sobre el tratamiento de la caída de la España visigoda y la ideología neogótica en la Silense, vid. LE Morvan, Gäel. «Reinos e imperio: la Historia legionensis (llamada silensis) y la reivindicación leonesa de la herencia visigótica». e-Spania, 2012, vol. 14 [en línea: http://e-spania.revues.org/21681].

6 Rodríguez de la PeÑa, Manuel Alejandro. «Ideología política y crónicas monásticas: la concepción cluniacense de la Realeza en la Espańa del siglo Xiı». Anuario de Estudios Medievales, 2000, vol. 30/2, pp. $699-700$.

7 Gil de Zamora, Juan. De Preconiis Hispaniae, ed. lat. M. de Castro y Castro; ed. esp. Alabanza de España, José Luis Martín. Zamora: Ayuntamiento de Zamora, 1995, VII, 1 y VII, 4, pp. 53-57.

8 RuCQuor, Adeline. «Contribution des studia generalia à la pensée hispanique médiévale». En Soto Rábanos, José María (coord.). Pensamiento medieval hispano: homenaje a Horacio Santiago Otero. Madrid: Consejo Superior de Investigaciones Científicas, 1998, pp. 739-740. 
MANUEL ALEJANDRO RODRÍGUEZ DE LA PEÑA

REALEZA SAPIENCIAL Y MECENAZGO CULTURAL EN LOS REINOS

DE LEÓN Y CASTILLA (IOOO-I 2OO)

Si tenemos en cuenta este dato, sobre el que insiste Rucquoi, que Jiménez de Rada habría oído sin duda hablar durante su estancia en la Universidad de París de la tradición que postulaba una translatio studii desde Atenas a París, podemos hacernos una idea de la importancia que dio don Rodrigo a este pasaje de la Getica que situaba a los herederos de los Godos en paridad con los Francos. Desde esta plataforma pudo unos años después Alfonso X añadir por su parte a la Laus Hispaniae isidoriana unas novedosas referencias sapienciales, que preparan el camino a las introducidas por Gil de Zamora en el pasaje del De Preconiis con el que abríamos este trabajo. En efecto, en el Loor de Espanna de la Primera Crónica General leemos cómo España es sobre todas engennosa, affincada en estudio y palaciana en palabra ${ }^{9}$, en lo que no deja de ser una vinculación de las virtudes de la sabiduría (propia de la esfera de los studia generalia) y la cortesía (propia de la esfera palatina).

De hecho, vincular a la monarquía y al mismo tiempo entre sí estos dos ámbitos socio-culturales, corte y escuela, universidad eclesiástica y palacio secular, Artes Liberales y cultura trovadoresca, en definitiva sacerdotium e imperium, fue el proyecto personal no solo de Alfonso X sino de muchos otros monarcas hispánicos de los siglos de la Reconquista, receptores de un ideal sapiencial europeo que inspiró el programa político de no pocos de los principales gobernantes del Occidente medieval.

\section{Alfonso III el Magno: un precursor}

Sin duda, el primer rey sabio de la época de la Reconquista fue Alfonso III de Asturias (r. 866-910), calificado como scientia clarus por el Albeldense, elogio que ningún cronista hizo de ningún otro de los reyes asturleoneses ${ }^{10}$. Similares epítetos ha recibido de la historiografía contemporánea desde que Claudio Sánchez-Albornoz le llamara «hombre de letras ${ }^{11}$ : alguien tan acreditado como Manuel C. Díaz y Díaz le describe como un «ferviente bibliófilo y devoto isidoriano», mientras que Gonzalo Menéndez Pidal le define como un "gran entusiasta de la cultura» ${ }^{12}$.

Heredero de la tradición sapiencial isidoriana y digno sucesor de monarcas intelectuales godos como Sisebuto (autor de un tratado astronómico en latín), Alfonso el Magno fue el primer soberano cristiano de la Reconquista que quiso o pudo reunir una biblioteca personal, ejerció un mecenazgo personal de intelectuales (por modesto que este fuera) y al

9 Alfonso X. Primera Crónica General de España, ed. A. García Solalinde. Madrid: Centro de Estudios Históricos, 1930, p. 311.

10 Y que este autor había aplicado anteriormente en su crónica a San Agustín (SÁncheZ-Albornoz, Claudio. Orígenes de la Nación española. El Reino de Asturias. Estudios críticos sobre la Historia del Reino de Asturias. Oviedo: Instituto de Estudios Asturianos, 1972-75, reed. Madrid, 1985, p. 337).

11 Sánchez-Albornoz, Orígenes de la Nación española, p. 337. Este juicio favorable lo desarrolla en otro pasaje: «por lo que sabemos de su bibliofilia, por el homenaje que rindió a su ciencia su contemporáneo llamado el Albeldense y porque con justicia debemos atribuirle la primera redacción de la crónica que lleva su nombre, podemos juzgar a Alfonso III amador de las Letras» (p. 303).

12 MenÉndez Pidal, Gonzalo. «Mozárabes y asturianos en la cultura de la Alta Edad Media (en relación especial con la historia de los conocimientos geográficos)». En Varia Medievalia. Madrid: Real Academia de la Historia, 2003, vol. I, p. 56. 
que además podemos atribuir la autoría (por matizable que esta sea) de un texto literario, la crónica latina que lleva su nombre (al menos en su versión llamada rotense) ${ }^{13}$.

En efecto, Alfonso III logró reunir numerosos códices latinos traídos por los clérigos mozárabes emigrados de al-Andalus ${ }^{14}$, haciendo copiar, con el ex-libris Adefonsi principis liber, uno de los más antiguos ejemplares hispánicos de las Etimologías de San Isidoro de Sevilla, en la actualidad el Scorialensis P.1.7. $7^{15}$. Asimismo, fue el Rey Magno quien hizo llevar a Oviedo los códices cordobeses de San Eulogio, cuyas reliquias también hizo trasladar a la civitas regia asturiana ${ }^{16}$.

Por otro lado, existe evidencia documental de encargos realizados por parte de Alfonso III a diversos scriptoria del Reino leonés para que copiaran libros para su biblioteca. La escriba Leodegundia copió para el monarca en el monasterio de Bobatelle un códice misceláneo que se conserva en El Escorial (a I 13). También se conserva en la biblioteca de El Escorial (T II 25) un códice con las Sentencias de San Isidoro copiado para el Rey Magno, además de códices con las obras de San Gregorio Magno, San Eusebio y San Rufino ${ }^{17}$.

La bibliofilia del soberano astur debió de ser tan notoria que en el año 882, el hachib del emir cordobés, Hasim ibn Abd al-Aziz, deseoso de conseguir la libertad de su hijo, al que había dejado como rehén tras la derrota sufrida a manos del Rey Magno, regaló a este dos códices muy valiosos: dos biblias, una cordobesa y otra sevillana, siendo ambas regaladas en el 908 a la iglesia de Oviedo ${ }^{18}$.

Entre los clérigos mozárabes emigrados de al-Andalus que entraron a su servicio en la corte ovetense probablemente figuró un toledano «muy erudito» llamado Dulcidio, autor de la llamada Crónica Profética y que parece que dio a conocer al soberano asturiano «alguna continuación de San Isidoro que llegara hasta Wamba y algún fragmento histórico donde se relataba el fin de la monarquía toledana desde el citado soberano hasta Rodrigo ${ }^{19}$. Es posible que también un clérigo ovetense elaborara por encargo suyo la crónica conocida como Albeldense ${ }^{20}$.

Esta labor de mecenazgo literario, si bien pobre si la comparamos con estándares carolingios o anglosajones de la época, justifica sin duda el juicio positivo de Ruiz de la Peña:

en el cultivo de las letras es precisamente en los decenios finales del siglo ix cuando se manifestará en toda su plenitud el alto nivel alcanzado por la cultura cortesana ovetense (...).

13 Sánchez-Albornoz, Orígenes de la Nación española, p. 337.

14 Menéndez Pidal, «Mozárabes y asturianos en la cultura», p. 56; Gómez-Moreno, Manuel. Iglesias mozárabes. Arte español de los siglos IX al XI. Madrid: Centro de Estudios Históricos, 1919, pp. 130 y 357.

15 Fontaine, Jacques. Isidoro de Sevilla. Génesis y originalidad de la cultura hispánica en tiempos de los Visigodos. Madrid: Encuentro, 2002, p. 292; MenÉNDEZ PidAL, «Mozárabes y asturianos en la cultura», p. 56.

16 MenÉndez Pidal, «Mozárabes y asturianos en la cultura», p. 56.

17 MenÉndez Pidal, «Mozárabes y asturianos en la cultura», p. 169.

18 SÁnchez-Albornoz, Orígenes de la Nación española, p. 300. Tal vez obsequio del hachib andalusí a Alfonso III fuera también el Ovetensis, hoy en El Escorial (R.II.16), pues en él se incluye el índice de una biblioteca, índice fechado precisamente en el mismo año 882 en que consiguió el rescate de su hijo.

19 Sánchez-Albornoz, Orígenes de la Nación española, pp. 298-299. En el año 883 Alfonso III envió a Dulcidio a Córdoba como su embajador a fin de negociar la paz con el Emir.

20 Sánchez-Albornoz, Orígenes de la Nación española, p. 337. 
MANUEL ALEJANDRO RODRÍGUEZ DE LA PEÑA

REALEZA SAPIENCIAL Y MECENAZGO CULTURAL EN LOS REINOS

DE LEÓN Y CASTILLA (I OOO-I 2OO)

Detrás de ese renacimiento literario estará, impulsando directamente, la propia personalidad del Rey, hombre de letras ${ }^{21}$.

Pero por encima de todo cabe resaltar que Alfonso el Magno fue el primero de una secuencia rica en príncipes escritores y cronistas en el Medievo hispánico: Alfonso el Sabio, Jaime el Conquistador, Pedro el Ceremonioso, don Duarte, el Príncipe de Viana... Sea como fuere, cabría preguntarse en primer lugar ¿cómo pudo un soberano ocupado por la guerra y la política sacar tiempo para compilar una crónica latina? Esta pregunta llevó a algunos a negar en su día la autoría regia sin tener en cuenta que un contemporáneo suyo, Alfredo el Grande de Wessex, enfrascado en una lucha sin cuartel contra los invasores vikingos, desplegó una actividad literaria mucho mayor ${ }^{22}$.

En este sentido, Sánchez-Albornoz elucubra del siguiente modo sobre el contexto creativo que llevó al Rey Magno a escribir la historia de su reino:

podemos imaginarle en el palacio de Santa María del Naranco o en el palacio de Oviedo escribiendo en el bárbaro latín que él manejaba la crónica que no he vacilado en atribuirle. Para redactarla dispuso de los textos que Dulcidio le había procurado sobre la historia gótica, del remoto cronicón perdido escrito a comienzos del reinado de Alfonso II, de la Crónica Profética y naturalmente de sus recuerdos personales ${ }^{23}$.

La crónica originalmente escrita por Alfonso III en torno al año 883 sería la conservada en el Códice de Roda y conocida como versión rotense ${ }^{24}$, un texto que ha llamado la atención por su pobre gramática latina, lo que hace creíble que la escribiera un laicus en la Asturias del siglo $\mathrm{x}^{25}$. El borrador o conjunto de materiales, hoy perdido, en el que

21 Ruiz de la Peña, Juan Ignacio. Crónicas asturianas, estudio preliminar. Oviedo: Servicio de Publicaciones, Universidad de Oviedo, 1985, p. 26.

${ }_{22}$ Collins, Roger. «Literacy in Early Medieval Spain». En McKitTerick, Rosamond (ed.). The Uses of Literacy in Early Medieval Europe. Cambridge: Cambridge University Press, 1990, p. 128; vid. BarrauDinigo, Louis. «Remarques sur la Chronique dite d'Alphonse III». Revue Hispanique, 1919, vol. 46, pp. 323-381. También se podrían aducir paralelismos con los monarcas carolingios y su cultivo de los saberes, una faceta de su acción política que tuvo gran relevancia en el caso de Carlomagno, Luis el Piadoso, Lotario I, Carlos el Calvo y Luis el Germánico. Ahora bien, a pesar de las embajadas carolingias a Oviedo en el siglo IX, no consta presencia de códices carolingios en las bibliotecas del Occidente hispánico anteriores al año 1000, salvo una obra de Smaragdo de Saint-Mihiel, por lo que cabe descartar una influencia ideológica directa del modelo carolingio en la Realeza astur-leonesa. Estamos ante una tradición sapiencial esencialmente visigóticomozárabe. Respecto a las bibliotecas hispánicas occidentales del periodo, cf. DíAz y DíAz, Manuel C. Códices visigóticos en la monarquía leonesa. León: Centro de Estudios e Investigación San Isidoro, 1983, pp. 179-190.

23 Sánchez-Albornoz, Orígenes de la Nación española, p. 299.

24 Sánchez-Albornoz, Orígenes de la Nación española, p. 337.

25 La relación entre su condición laical y su pobre latín ha sido así ponderada: «Lo de ser un laico, por sabio que pareciese, y un guerrero el autor de nuestro relato, justifica el tono de sus narraciones y el lenguaje; su barbarie, llamémosla así, por una educación incompleta que dejaba traslucir el habla vulgar de entonces, con tendencia a eliminar la declinación, sobre todo en los nombres propios, desconcierto en el uso de partículas y reglas de sintaxis, miseria de vocabulario, construcción monótona y sencillísima, y en cambio, un prurito por asonantar los finales de frase, que viene a constituir la única gala de tan pobre literatura. Esta perversión de estilo, apenas contaminado por la fraseología escolástica de los clérigos, se ajusta muy bien a la llaneza expositiva y calor de las evocaciones históricas» (Gómez-Moreno, Manuel. «Las primeras crónicas de la Reconquista». Boletín de la Real Academia de la Historia, 1932, vol. 100, p. 586). 
se apoyó el monarca, acaso el proporcionado por Dulcidio, parece que fue retocado y mejorado en su latín por algún clérigo de su entorno áulico en una segunda versión de la crónica conocida como ovetense o ad Sebastianum ${ }^{26}$.

En realidad, la parte original de la crónica no va mucho más allá de un somero relato del reinado de su padre, Ordońo I (r. 850-866). Además, mucho se ha escrito sobre el «estilo bárbaro» ${ }^{27}$ y caótico del latín de la crónica del Rey Magno. Con todo, el texto rotense está lleno de citas bíblicas, fraseología legal y rasgos de estilo literario de gusto visigótico $^{28}$. Tal y como ha subrayado Roger Wright, conviene tener en cuenta que «el rey Alfonso III y los de su corte no eran ni bárbaros ni torpes ni totalmente decadentes, y ya es hora de reenfocar, de una manera más generosa y más comprensiva, la evaluación que damos a sus textos ${ }^{29}$. Al fin y a la postre bien pudiera ser, como propone Wright, que efectivamente Alfonso III y sus adláteres estuvieran escribiendo un texto romance "en un estilo altísimo" y no un texto latino "en un estilo bajísimo» ${ }^{30}$.

No es menos cierto, por otra parte, que el mero hecho de que un monarca del oscuro siglo Ix hispánico, un auténtico "siglo de hierro» para la Espańa cristiana, fuera capaz de dominar el latín con suficiente destreza como para componer una crónica ya es remarcable en sí mismo más allá de discusiones sobre la calidad gramatical de su prosa. Roger Collins así lo ha visto y ha apuntado que la Crónica de Alfonso III es «quizá el testimonio más impactante de la cultura literaria de los laicos y su interés por el saber en las sociedades de la Alta Edad Media hispánica»" ${ }^{31}$.

Desgraciadamente, tal y como apunta el propio Collins, Alfonso III «fracasó a la hora de transmitir a sus aguerridos sucesores su modelo de actuación intelectual de la Realeza» (model of royal participation in scholarship) ${ }^{32}$, por lo que habría que esperar casi siglo y medio para volver a discernir en las fuentes indicios de mecenazgo regio de la cultura en los reinos occidentales de la Península Ibérica.

26 La antigua tesis de que la versión ovetense se apoyó en el texto rotense del rey Alfonso no ha convencido a la historiografía más reciente, dado que las divergencias entre las dos versiones son bastante acusadas. En esta dirección, hay autores que sostienen que la ovetense no se limitó a enmendar el texto rotense, sino un borrador más antiguo hoy perdido. Por ejemplo, Jan Prelog, Manuel C. Díaz y Díaz y Juan Gil han propuesto una completa independencia de la rotense y la ovetense, dependiendo ambas de un texto previo anterior, que es lo que explicaría su paralelismo. Esa misma percepción sería válida para el relato sobre los reyes astures de la Albeldense, que procedería de esa primera versión de la crónica, acaso un mero borrador, mientras que la crónica debida a la mano de Alfonso III derivaría de una versión retocada de ese texto primigenio (DíAz y DíAz, Manuel C. Libros y librerías en La Rioja altomedieval. Logrońo: Servicio de Cultura de la Excma. Diputación Provincial, 1979, p. 37; vid. Prelog, Jan. Die Chronik Alfons' III. Untersuchung und kritische Edition der vier Redaktionen. Frankfurt: Lang, 1980, estudio introductorio).

27 Gómez-Moreno, «Las primeras crónicas», p. 585. Sánchez Alonso, García de Valdeavellano, Stero, Gil Fernández y Prelog, entre otros, se han hecho eco de este duro juicio, con expresiones que van de «latinidad ulcerada» a «estilo miserable».

28 WRIght, Roger. «Textos asturianos de los siglos IX y x. Latín bárbaro o romance escrito». Lletres Asturianes, 1991, vol. 41, p. 23.

29 WRIGHT, "Textos asturianos de los siglos IX y X», pp. 21 y 32.

30 Wright, "Textos asturianos de los siglos IX y X», p. 23.

31 Collins, «Literacy in Early Medieval Spain», p. 128.

32 Collins, «Literacy in Early Medieval Spain», p. 128. 
MANUEL ALEJANDRO RODRÍGUEZ DE LA PEÑA

REALEZA SAPIENCIAL Y MECENAZGO CULTURAL EN LOS REINOS

DE LEÓN Y CASTILLA (IOOO-I 2OO)

\section{León en el siglo XI: Fernando I y la Reina Sancha}

En efecto, no sería hasta el reinado de Fernando I de León y Castilla (r. 1035-1065), cuando se produjera de nuevo un cierto «renacimiento cultural» hispánico ${ }^{33}$, si bien de mínimas proporciones si lo ponemos en un contexto europeo. De una particular relevancia es el mecenazgo regio en relación al conjunto monumental de San Isidoro de León, en el que la reina Sancha jugó un papel decisivo como domina del monasterio ${ }^{34}$.

La abadía-palacio de San Isidoro de León «fue uno de los goznes sobre los que pivotó la gestación y desarrollo de la producción artística en el Reino de León -y, por extensión, en los territorios cristianos peninsulares- durante los siglos XI y XII. En este lugar, cinco generaciones sucesivas del linaje regio leonés, mujeres principalmente, auspiciaron iniciativas devocionales y artísticas imprescindibles para comprender las trayectorias recorridas por el arte románico hispano» ${ }^{35}$.

Con el extraordinario conjunto palatino de San Isidoro de León como epicentro, Fernando I y la reina Sancha desplegaron un mecenazgo artístico muy remarcable en una época en la que, tal y como ha subrayado John Williams, «sería de esperar que fuera más significativo el mecenazgo monástico y no el regio» ${ }^{36}$. La existencia de un activo taller palatino de orfebrería y talla de marfil ha sido sugerida a partir del estudio de las piezas ligadas a la corte en las que se percibe una gran homogeneidad de factura. Esta producción artística ha llevado a John Williams a poner de relieve que la ciudad de León bajo Fernando y Sancha mostró «una peculiar concentración de mecenazgo del tipo que solemos asociar con centros imperiales como el Aquisgrán otónida de los siglos x y xI ${ }^{37}$.

Hubo también, sin duda, un importante mecenazgo regio de la producción de códices miniados, en el que la esposa del rey Fernando, la reina Sancha, tuvo un decisivo pape ${ }^{38}$.

33 MenÉndez Pidal, «Mozárabes y asturianos en la cultura», p. 174.

34 Sobre la relación entre San Isidoro de León y la monarquía leonesa, vid. Henriet, Patrick. "Un exemple de religiosité politique: Saint Isidore et les rois de León (XI ${ }^{\mathrm{e}}$-XIII ${ }^{\mathrm{e}}$ siècles)». En DerWICH, Marek y DMITRIEV, Michel (eds.). Fonctions sociales et politiques du culte des saints dans les societés de rite grec et latin au Moyen Âge et à l'époque moderne. Approche comparative. Wrockaw: Larhcor, 1999, pp. 77-93. Para el contexto, vid. IsLA FreZ, Amancio. Memoria, culto y monarquía hispánica entre los siglos X y XII. Jaén: Universidad de Jaén, 2007.

35 Boto Varela, Gerardo. «Las Dueńas de la memoria. San Isidoro de León y sus Infantas». Románico, 2010, vol. 10, p. 75 .

36 Williams, John. «Fernando I and Alfonso VI as Patrons of the Arts». Anales de Historia del Arte, 2011, vol. extraordinario 2, p. 413.

37 Williams, John. «León: The Iconography of a Capital». En Bisson, Thomas N. (ed.). Cultures of Power. Lordship, Status, and Process in Twelfth-Century Europe. Philadelphia: University of Pennsylvania Press, 1995, p. 237.

38 «Sin restar importancia al patrocinio artístico de Fernando I, la reina Sancha se distingue más que su esposo como promotora y propietaria de códices» (SÁENZ-López Pérez, Sandra. «El mundo para una reina: los mappaemundi de Sancha de León (1013-1067)». Anales de Historia del Arte, 2010, vol. extraordinario 2, p. 319). En este mismo sentido, Elisa Ruiz ha señalado que la reina Sancha utilizaba sus libros, y otros objetos suntuarios, como una forma de refrendar la legitimidad dinástica del propio Fernando, cuyo origen en lo tocante al trono de León era ella misma (vid. Ruiz García, Elisa. «Arma regis: Los libros de Fernando I y dońa Sancha (1035-1065)». En Los reyes bibliófilos, ed. A. B. Sánchez Prieto, Madrid, en prensa). Para una reciente revisión de esta importante figura, vid. KLINKA, Emmanuelle. «Sancha, infanta y reina de León». e-Spania, 2008, vol. 5 [en línea: http://e-spania.revues.org/11033]. 


\section{MANUEL ALEJANDRO RODRÍGUEZ DE LA PEÑA \\ REALEZA SAPIENCIAL Y MECENAZGO CULTURAL EN LOS REINOS DE LEÓN Y CASTILLA (IOOO-I 200)}

En efecto, se conservan hoy una serie de códices (de forma aleatoria, lo que indica que pudieron ser muchos más) en los que aparece mencionada expresamente como impulsora de su elaboración. Para ella se copiaron varios códices de gran valor artístico: en 1047 el escriba Domingo copió las Etimologías de San Isidoro (El Escorial, E I 3) ${ }^{39}$, el escriba Christoforus un Breviario mozárabe (Liber canticarum et horarum, c 1059) ${ }^{40}$ y hacia 1055 la reina (junto con su esposo) encargaba al escriba Pedro y al miniaturista Fructuoso un bello Libro de Horas, o Diurnal, de estilo románico que fue entregado a la sede compostelana ${ }^{41}$. Además, se copió para la biblioteca real un «lujosísimo» ejemplar de los Comentarios al Apocalipsis de Beato de Liébana (c 1047), único en su género por el valor artístico de sus miniaturas ${ }^{42}$.

Todos estos códices muestran similitudes estilísticas (en las formas zoomórficas, en el uso de colores con tonalidades semejantes o la forma de las letras unciales) que «apuntan hacia un scriptorium común o un área cultural limitada que utiliza un mismo modelo gráfico» a pesar del tiempo transcurrido entre la elaboración de los diferentes códices y el cambio de copista ${ }^{43}$. Este scriptorium bajo patrocinio regio probablemente sería el del monasterio de San Juan de León, posteriormente San Isidoro.

Por otra parte, dos de estos códices, el Comentario al Apocalipsis de Beato de Liébana y las Etimologías de San Isidoro, comparten una llamativa característica común, pues integran entre sus ilustraciones una imago mundi, una suerte de mappae mundi: dos en

39 Sobre este manuscrito, cf. DíAz y DíAz, Manuel C. «Problemas de algunos manuscritos hispánicos de las Etimologías de Isidoro de Sevilla». En Autenrieth, Johanne und Brunhölzl, Franz (eds.). Festschrift Bernhard Bischoff zu seinem 65. Geburtstag. Stuttgart: Anton Hiersemann, 1971, pp. 73-74. Vid. también los trabajos inéditos de Kume, Junko. Aportaciones al estudio de las Etimologías de Doña Sancha de León (Real Biblioteca de El Escorial, o. I. 3), Trabajo de investigación de doctorado inédito, Universidad Complutense de Madrid, 2006 y «Transmisión y enriquecimiento de programas iconográficos en la Alta Edad Media: el caso de las Etimologías de doña Sancha de León». Actas del XVII Congreso Nacional de Historia del Arte, CEHA2008, Art i memoria. Barcelona, 2008, en prensa.

40 Conservado en la biblioteca de la Universidad de Salamanca (ms. 2668). Contiene una notación melódica que indica una recepción de la notación musical carolingia. Sobre este códice, vid. KLINKA, Emmanuelle. "Ego misera et peccatrix...: El Liber mozarabicus canticorum et horarum (Salamanca, ms. 2668)». e-Spania, 2012, vol. 13 [en línea: http://e-spania.revues.org/21044]; y Galván Freile, Fernando. «El Liber Canticorum et Horarum de Sancha (B.G.U.S., MS. 2668): entre la tradición prerrománica y la modernidad». En Arbeiter, Achim et al. (ed.). Hispaniens norden im 11. Jahrhundert. Christliche Kunst im Umbruch. Petersberg: Imhof Verlag, 2009, pp. 248-256.

41 Conservado en la biblioteca de la Universidad de Santiago (Res. 1). Todo apunta a que la iluminación de este códice introdujo la miniatura «románica» por vez primera en el Reino leonés (WiLliams, «León: The Iconography of a Capital», p. 240). Sobre este códice, vid. FÉrotin, Marius. "Deux manuscrits wisigothiques de la Bibliothèque de Ferdinand I ${ }^{\mathrm{er}}$ ". Bibliothèque de l'École des Chartes, 1901, vol. 62, pp. 374-387; DíAz y Díaz, Códices visigóticos, pp. 289-291; y Moralejo Álvarez, Serafín. "Notas a la ilustración del Libro de Horas de Fernando I». En Díaz y Díaz, Manuel C. Libro de Horas de Fernando I de León. Edición facsímile do manuscrito 609 (Res. 1) da Biblioteca Universitaria de Santiago de Compostela. Santiago de Compostela: Xunta de Galicia, 1995, pp. 53-63.

42 Menéndez Pidal, «Mozárabes y asturianos en la cultura», p. 174; Boto Varela, "Las Dueñas de la memoria», p. 77. El códice con los comentarios del Apocalipsis de Beato de Liébana es un ejemplar único de inmenso valor artístico (vid. Werckmeister, Karl. «The First Romanesque Beatus Manuscripts and the Liturgy of Death». En Actas del Simposio para el estudio de los códices del Comentario al Apocalipsis de Beato de Liébana. Madrid: Joyas Bibliográficas, 1978-1980, vol. 1, pp. 167-192).

43 KLinka, "Ego misera et peccatrix», p. 3. 
MANUEL ALEJANDRO RODRÍGUEZ DE LA PEÑA

REALEZA SAPIENCIAL Y MECENAZGO CULTURAL EN LOS REINOS

DE LEÓN Y CASTILLA (IOOO-I 200)

el Comentario de Beato y uno en las Etimologías. Estos tres mapas han sido vinculados a los intereses de la reina y bautizados por una especialista como «los mappaemundi de doña Sancha» ${ }^{44}$.

Cabe concluir, por consiguiente, que Fernando I y doña Sancha poseyeron algún tipo de biblioteca palatina, si bien no es posible calibrar sus dimensiones. Además, la Historia Silense (c. 81) consigna un hecho significativo: Fernando I dispuso que sus hijos, tres de ellos futuros monarcas, recibieran educación en las Artes Liberales (liberalibus disciplinis erudirentur) ${ }^{45}$, además de en el manejo de las armas, la caza y la equitación, siendo esta la primera mención de una educación palatina para los infantes reales consignada en las fuentes hispánicas medievales ${ }^{46}$. Resulta llamativo, asimismo, que sus hijas también sean mencionadas como receptoras de esta educación. De hecho, la infanta doña Urraca continuará la labor de mecenazgo artístico de su madre en San Isidoro de León ${ }^{47}$.

Precisamente al final de su crónica, el Silense se las ingenia para describir, con mano maestra, una escena que entra de lleno dentro de las imágenes sapienciales de la Realeza davídica y salomónica. Durante la ceremonia de celebración de la Navidad, un coro de clérigos entonó en presencia del rey castellano un canto de maitines según el rito mozárabe, more toletano. En él se invoca el precepto salomónico del Libro de los Proverbios tantas veces repetido en el Medievo sobre la necesidad de que los reyes sean sabios: Erudimini omnes qui iudicatis terram. El cronista se apresura a declarar que Fernando lo ha cumplido plenamente, ya que ha gobernado católicamente el reino como Rex eruditus ${ }^{48}$.

A nuestro juicio resulta plausible que el Silense estableciera en su crónica una justificación ideológica de raíz bíblica para el perfil sapiencial del monarca castellano, un perfil no imaginario aunque desde luego sometido a una amplificatio retórica. Una narrativa de la legitimación del poder regio que nos presenta un modelo de Realeza davídicosalomónica en el que encajaría perfectamente tanto el mecenazgo regio anteriormente analizado como la educación liberal proporcionada a sus hijos.

44 SÁenz-López PÉrez, «El mundo para una reina», p. 320.

45 Rex vero Fernandus filios suos et filias ita censuit instruere, ut primo liberalibus disciplinis, quibus et ipse studium dederat, erudirentur; dein, ubi etas patiebatur, more ispanorum equos cursare, armis et venationibus filios exercere fecit (Historia Silence, c. 81).

46 Rucquor, Adeline. «Éducation et société dans la Péninsule Ibérique médiévale». Histoire de l'Éducation, 1996, vol. 69, p. 9; y «Alfonso VIII de Castilla y la Realeza». En RucQuoI, Adeline. Rex, Sapientia, Nobilitas. Estudios sobre la Peninsula Ibérica medieval. Granada: Editorial Universidad de Granada, 2006, p. 54. De hecho, Alfonso VI llama en sus diplomas magistro nostro a Raimundo, obispo de Palencia.

47 Havens Caldwell, Susan. "Urraca of Zamora and San Isidoro in León: Fulfilment of a Legacy». Woman's Art Journal, 1986, vol. 7/1, p. 21; y MARTIN, Thérèse. «Mujeres, hermanas e hijas: el mecenazgo femenino en la familia de Alfonso VI». Anales de Historia del Arte, 2011, vol. extraordinario 2, pp. 148-150. Susan Havens subraya la educación literaria recibida por la infanta en conexión con su actividad de mecenazgo artístico (p. 149). Sobre este mecenazgo en relación a San Isidoro, cf. Boto Varela, «Las Dueñas de la memoria», pp. 77-78.

48 Historia Silense, c. 105: Ceterum in ipsa celebri nativitatis Dominice nocte, cum clerici festivo more natalicium matutinum canerent, adfuit inter eos dompnus rex, atque virtute que poterat letus concinere cepit ultimum sonum matutinorum: "Advenit nobis", quem nunc temporis more Toletano canebant, succentoribus autem respondentibus: "Erudimini omnes qui iudicatis terram", quod Fernando serenissimo regi non incongrue tunc conveniebant, qui dum vivere sibi licuit, et regnum catholice gubernavit et seipsum, presso impudicicie freno, funditus eruditum reddidit. En torno al contexto litúrgico y teológico de este pasaje del Silense, vid. Bishкo, Charles Julian. "The Liturgical Context of Fernando I’s Last Days». Hispania Sacra, 1964, vol. 17, pp. 33-45 y $47-49$. 
Precisamente, Emmanuelle Klinka ha llamado la atención sobre la asociación de Fernando I con la figura del rey David en los códices producidos por los copistas del entorno palatino. Por ejemplo, el soberano castellano-leonés es representado como una figura majestuosa davídica en el Alfa del Apocalipsis del Beato del año 1047 (fol. 6v) y en el incipit del Diurnal entregado por los reyes a Compostela (fol. 29v) ${ }^{49}$.

Además, en la escena de presentación de este mismo Libro de Horas, Joaquín Yarza ha visto en la figura con los pies descalzos una representación penitencial del rey David, apuntando que se pretendía con ello exaltar a Fernando como imperator leonés, ya que, además de ostentar atributos regios -corona y cetro-, se exhibe como posesor de un llamativo salterio de oro, lo que le vincularía al Rey Salmista ${ }^{50}$. A nadie se le oculta que la iconografía regia davídica tenía connotaciones sacrales y sapienciales profundas, dado el poderoso perfil profético del Rey Salmista como sabio y músico, el soberano mesiánico inspirado por Yahvé que anticiparía la figura del propio Cristo ${ }^{51}$.

En definitiva, el mecenazgo cultural y la imagen sapiencial regios encarnados por Fernando I y su esposa presentan llamativos paralelismos con el programa político de los emperadores otónidas y salios del siglo XI. Además de recurrir frecuentemente a la imagen davídica o salomónica de la Realeza ${ }^{52}$, Otón III, Enrique II y Enrique III desplegaron un mecenazgo artístico y cultural imbricado en un discurso sapiencial de la translatio imperii como translatio studii (Aquisgrán como tercera Roma), que guarda ciertas similitudes con lo que hemos analizado anteriormente en la corte leonesa del periodo fernandino.

En este sentido, resulta particularmente interesante el paralelismo ideológico con el emperador salio Enrique III (imp. 1039-1056), estricto contemporáneo de Fernando I y tan vinculado a la órbita espiritual y cultural de Cluny como el soberano de León y Castilla. Enrique III es descrito por su capellán Wipo como un Rex eruditus y bibliófilo (Tetralogus, vv. 158-162), alguien que impulsaba debates intelectuales entre los sabios de su corte y cuyo mecenazgo artístico, si hemos de creer a los Annales de Augsburgo, produjo un florecimiento de la vida cultural en Alemania ${ }^{53}$. Además, el importante papel jugado

49 KLINKA, "Ego misera et peccatrix», p. 4: "Al pretender imponer la figura del rey don Fernando I como el nuevo David, recurrieron a una serie de símbolos, entre los cuales la majestuosidad figurativa que el tratamiento románico proporcionaba al dibujo».

50 Yarza Luaces, Joaquín. Arte y arquitectura en España 500-1250. 6. a ed. Madrid: Cátedra, 1990, pp. 167-168; Williams, «Fernando I and Alfonso VI as Patrons of the Arts», pp. 419 y 424 . Sobre el imaginario político de este Libro de Horas, vid. Castiñeiras González, Manuel. «Algunos usos y funciones de la imagen en la miniatura hispánica del siglo xi: los Libros de Horas de Fernando I y Sancha». En Congresso Peninsular de História da Arte. Propaganda \& poder. Lisboa: Colibrí, 2000, pp. 74-94.

51 Sobre el uso de la figura davídica en el pensamiento político medieval, vid. STEger, Hugo. David rex et Propheta. König David als Vorbildlicher Verkörperung des Herrschers und Dichters im Mittelalter, nach Bilddarstellungen des achten bis zwölften Jahrhunderts. Nürnberg: Verlag Hans Carl, 1961.

52 Weinfurter, Stefan. The Salian Century. Main currents in an Age of transition. Philadelphia: University Pennsylvania Press, 1999, p. 89; Klaniczay, Gabor. "The Ambivalent Model of Solomon for Royal Sainthood and Royal Wisdom». En Biliarsky, Ivan et al. (ed.). The Biblical Models of Power and Law: Papers of the International Conference. Frankfurt: Peter Lang GmbH, 2008, p. 77; vid. ScHmidT, Paul Gerhard. "Heinrich III. Das Bild des Herrschers in der Literatur seiner Zeit». Deutsches Archiv, 1983 , vol. 39, pp. 582-590.

53 Weinfurter, The Salian Century, p. 97. 
MANUEL ALEJANDRO RODRÍGUEZ DE LA PEÑA

REALEZA SAPIENCIAL Y MECENAZGO CULTURAL EN LOS REINOS

DE LEÓN Y CASTILLA (IOOO-I 200)

por la reina Sancha recuerda al mecenazgo artístico y cultural desplegado por las emperatrices Teófano y Adelaida en el periodo otónida ${ }^{54}$.

No menos significativos resultan, en esta dirección, los numerosos paralelismos descubiertos por los historiadores del arte entre algunas piezas artísticas, sobre todo de orfebrería, facturadas o encargadas por el entorno áulico leonés de esta época y modelos otonianos, unas similitudes no solo formales sino también iconográficas ${ }^{55}$. También resulta «muy sugerente» a juicio de Manuel Castińeiras la comparación entre la estética de las páginas de algunos manuscritos leoneses del reinado fernandino y la tradición aúlicaimperial de manuscritos otonianos de letras doradas sobre fondo purpúreo ${ }^{56}$.

A pesar de la presunta educación que habría recibido Alfonso VI en las Artes Liberales según el Silense lo cierto es que no hay evidencia alguna de una actividad de mecenazgo artístico o intelectual directo de este gran monarca de León y Castilla ${ }^{57}$, lo que contrasta con la destacada actividad de sus hermanas y esposas en ese campo ${ }^{58}$. Ni las crónicas que cubren su reinado ni la documentación superviviente testimonian inquietudes de este tipo

54 Thérèse Martin ha puesto de relieve los paralelismos existentes entre el mecenazgo femenino áulico en León y la Alemania imperial de los siglos x y Xi (MARTin, «Mujeres, hermanas e hijas», pp. 151-156). Para un detallado análisis del mecenazgo regio femenino otónida, cf. McKitTerick, Rosamond. «Ottonian Intellectual Culture in the Tenth Century and the Role of Theophanu». Early Medieval Europe, 1993, vol. 2/1, pp. 55, 57, 59 y $62-63$.

55 Varios autores han subrayado esta inspiración otónida de la orfebrería leonesa, claramente percibible en varias piezas. En particular, las conexiones entre los emperadores teutones y los soberanos de León se han estudiado a través de las donaciones de Fernando I y Sancha a la abadía de Cluny y el tesoro con el que obsequiaron a su iglesia palatina de San Isidoro en 1063 para festejar la traslación de las reliquias del santo hispalense (Martin, «Mujeres, hermanas e hijas», pp. 154-156; vid. Moralejo Álvarez, Serafín. "Ars sacra et sculpture romane monumentale: le trésor et le chantier de Compostelle». Les Cahiers de Saint-Michel de Cuxa, 1980, vol. 2, pp. 189-238). Quizá el ejemplo más espectacular de esta recepción de formas artísticas otónidas sea el arca de plata de las reliquias de San Isidoro, cuyas figuras en relieve parecen inspiradas en las de las famosas puertas de bronce de la abadía otoniana de San Miguel de Hildesheim (vid. Gómez-Moreno, Manuel. "El arca de las reliquias de San Isidoro de León». Archivo Español de Arte y Arqueología, 1932, vol. 7, pp. 205-212). Posteriormente este investigador cambió de opinión y atribuyó el arca al reinado de Sancho III el Mayor, pero la cuestión sigue abierta (En torno al crucifijo de los reyes Fernando y Sancha. Madrid: Instituto de Restauración, 1965, pp. 7-8).

56 Castiñeiras González, Manuel. "Libro de Horas de Fernando I y Sancha». En Valle Pérez, José Carlos (coord.). Enciclopedia del Románico en Galicia. A Coruña. Aguilar de Campoo: Fundación Santa María la Real, 2013, vol. 2, p. 1144. Este investigador también apunta a un modelo carolingio para el Libro de Horas de Fernando y Sancha: «la inclusión en el códice de parte del texto de Alcuino de York, De psalmorum usu liber (f. 5rv) -composición destinada a difundir la recitación de los salmos entre los laicos-, así como de una oración de san Agustín a la Santa Trinidad (ff. 195r-196v), permiten poner dicha obra en relación con el Libro de Horas de Carlos el Calvo... Que el prefacio del texto de Alcuino de York esté precisamente recogido en el Libro de Horas de Fernando I... nos proporciona una inestimable ayuda para entender el uso del Salterio, algunas peculiaridades de su iluminación, así como las vinculaciones de su decoración con precedentes carolingios-otonianos» (CASTiÑeIras GonZÁleZ, "Libro de Horas», pp. 1143 y 1145).

57 Así lo ha recalcado Rose Walker: «there is little evidence for his personal involvement in architectural projects or in other acts of artistic patronage» («Becoming Alfonso VI: the king, his sister and the arca santa reliquary». Anales de Historia del Arte, 2011, vol. extraordinario 2, p. 396).

58 Williams, «Fernando I and Alfonso VI as Patrons of the Arts», pp. 427-428; vid. Martin, Thérèse. Queen as King: Politics and Architectural Propaganda in Twelfth-Century Spain. Leiden: Brill, 2006; y «Mujeres, hermanas e hijas". 
en el conquistador de Toledo ${ }^{59}$. Todo lo más, encontramos algunos indicios de donaciones de objetos de cierto valor artístico. No a San Isidoro de León, que entregó por completo al patronazgo de su hermana Urraca, pero sí a su abadía favorita: Sahagún.

De esta forma, se sabe que, además de promover la erección de un nuevo panteón real y edificar un complejo palatino en la abadía a instancias de su esposa Constanza de Borgoña († 1093), Alfonso VI donó a los monjes cluniacenses de Sahagún un impresionante altar de plata de cinco metros de largo con figuras de relieve ${ }^{60}$. Esta generosa donación, conjuntamente con la entrega de sendos crucifijos de oro con piedras preciosas a las iglesias de Nogal y San Salvador de Villaverde de Valdevidriales, resulta ser la única acción de mecenazgo artístico del soberano de la que ha quedado constancia. Un balance bien pobre y particularmente inexplicable salvo que se recurra a la escasez de las fuentes de que disponemos.

\section{El siglo XII: ¿Un Renacimiento para León y Castilla?}

Lo cierto es que el panorama cultural de la corte regia de la primera mitad del siglo XII en el occidente peninsular es de una gran pobreza en casi todos los campos, no produciéndose un despertar hasta la coronación imperial de Alfonso VII en 1135. Esta ausencia de mecenazgo cultural ciertamente no se puede desligar de la profunda crisis del reinado de la reina Urraca, crisis que quizá explique por sí sola esta realidad. Con todo, la cuestión estriba en si la ausencia de mecenazgo regio tuvo algún efecto en el panorama general de la cultura de León y Castilla en la primera mitad del siglo XII.

Sea como fuere, cabe subrayar que fue precisamente en esta primera mitad del siglo XII, debido sobre todo al impulso de obispos ligados a la órbita de Cluny como Diego Gelmírez y Raimundo de Toledo, cuando se produjeron dos brillantes episodios de la historia cultural del Occidente europeo: la edificación de la nueva basílica de Santiago de Compostela, auténtico culmen del románico, y la fundación de la llamada Escuela de Traductores en Toledo, tan decisiva para el proceso de recepción de la ciencia griega y arábiga en la Europa latina. Significativamente, estas dos realizaciones se produjeron completamente al margen de la monarquía y en torno al episcopado.

Por el contrario, en la segunda mitad del siglo XII nos encontramos con un panorama muy diferente. Un ejemplo significativo lo encontramos en la propia basílica compostelana, donde su artífice más genial y reconocido, el maestro Mateo, recibía la concesión de cien maravedíes anuales vitalicios por parte del rey Fernando II de León, quien intentaría así «imprimir un sello real» al templo jacobeo. Así pues, «desde el año 1168, la fábrica de la catedral no dependía ya del cabildo catedralicio sino de la corte real» leonesa ${ }^{61}$.

59 Conviene no mezclar aquí parámetros de actuación regia. Por ejemplo, su donación de 30.000 dinares de oro para la erección de una nueva basílica en Compostela en el año 1075 no le convierte en un mecenas artístico, sino en un soberano piadoso, un Rex pius.

60 Williams, «Fernando I and Alfonso VI as Patrons of the Arts», p. 429.

61 Documento de Fernando II datado el 23 de febrero de 1168 (Karge, Henrik. «De la portada románica de la transfiguración al Pórtico de la Gloria. Nuevas investigaciones sobre la fachada occidental de la catedral de Santiago de Compostela». Boletín del Seminario de Estudios de Arte, 2009, vol. 75, p. 22). 
MANUEL ALEJANDRO RODRÍGUEZ DE LA PEÑA

REALEZA SAPIENCIAL Y MECENAZGO CULTURAL EN LOS REINOS

DE LEÓN Y CASTILLA (IOOO-I 200)

Pero si en el Camino de Santiago y en Toledo florecían las artes y los saberes del Quadrivium, en otro orden de cosas la Espańa cristiana aún era un lugar atrasado en muchos aspectos con respecto a la Europa de allende los Pirineos. En efecto, a pesar del despegue que experimentó la enseñanza en las escuelas catedralicias en la segunda mitad del siglo $\mathrm{XII}^{62}$, parece que no hubo antes de 1200 en los reinos de León y Castilla una sola escuela de leyes para la formación de juristas romanistas ${ }^{63}$. Acaso una excepción fuera la abadía de San Servando de Toledo, con fuertes vínculos con San Víctor de Marsella, un centro monástico donde se estudiaba el derecho canónico, o, ¿por qué no?, con el capítulo de Sigüenza, donde muchos canónigos regulares eran canonistas ${ }^{64}$.

En cualquier caso, más allá de los juristas ultrapirenaicos que pudieran haber enseńado leyes en la Universidad de Palencia a partir de $1180^{65}$, entre los que destaca el nombre del magister italiano formado en Bolonia Hugolino de Sesso $(\dagger 1235)^{66}$, los pocos iuris periti entonces disponibles en León y Castilla eran clérigos y habían sido formados en su inmensa mayoría al norte de los Pirineos, en Bolonia, Cremona y Montpellier ${ }^{67}$.

Otro indicio de la precariedad absoluta de la intelligentsia clerical al servicio de los monarcas de León y Castilla en la primera mitad del siglo XII lo encontramos en el número de escribanos adscritos a la cancillería regia. Al igual que ya sucediera en el siglo XI, cuando se dependía en gran medida de los scriptoria monásticos para la producción de documentos reales, se ha comprobado que casi la totalidad de los documentos de Alfonso VII y Fernando II datados en León ofrecen «un tipo de escritura idéntico al usado en los documentos del cabildo catedral ${ }^{68}$. Esto parece indicar que la cancillería real, ante la carencia de personal propio más allá del canciller y unos pocos notarios, se servía de los

62 González, Julio. El reino de Castilla en la época de Alfonso VIII. Madrid: Escuela de Estudios Medievales, 1960, vol. 1, p. 626. Este despegue antecedió a las disposiciones educativas del IV Concilio de Letrán (1215), tradicionalmente considerado como una cesura en este aspecto.

63 Post, Gaines. «Roman Law and Early Representation in Spain and Italy, 1150-1250». Speculum, 1943, vol. 18/2, pp. 216-217. Ejemplos seńalados de estos clérigos juristas de la segunda mitad del siglo XII son el catalán Pedro de Cardona, profesor en Montpellier y luego cardenal, y los canonistas Pedro Hispano ( $f$. 1190) y Juan Hispano (que trabajó en la curia pontificia hacia 1186).

${ }_{64}$ Linehan, Peter. History and the Historians of Medieval Spain. Oxford: Clarendon Press, 1993, p. 307, n. 165 .

65 Durante un tiempo se rechazó la presencia de juristas entre los magistri de leyes en el primer periodo palentino simplemente porque el Tudense (que habla de magistros theologicos et aliarum artium) y el Toledano no los mencionaban expresamente. Actualmente esta presencia se considera segura. Véanse los trabajos de Barcala, Andrés. "Las universidades espańolas durante la Edad Media». Anuario de Estudios Medievales, 1985, vol. 15, pp. 83-126, especialmente p. 91; Iglesia Ferreirós, Aquilino. «Escuela, Estudio y maestros». Historia, Instituciones, Documentos, 1998, vol. 25, p. 313, n. 1.

66 Gouron, André. «Aux origines de l'influence des glossateurs en Espagne». Historia, Instituciones, Documentos, 1984, vol. 10, p. 325; cf. IGLEsia Ferreirós, Aquilino. «Rex superiorem non recognoscens: Hugolino de Sesso y el Studium de Palencia». Initium. Revista Catalana d'Història del Dret, 1998, vol. 3, pp. 1-205.

67 Cf. Gouron, «Aux origines de l'influence des glossateurs», pp. 325-346; vid. MAffei, Domenico. «Fra Cremona, Montpellier e Palencia nel secolo XII». Rivista Internazionale di Diritto Comune, 1990, vol. 1, pp. 9-30.

68 Sierra Macarrón, Leonor. «La escritura y el poder. El aumento de la producción escrita en Castilla y León (siglos XI-XIII)». Signo, 2001, vol. 8, p. 255. 
escribanos del obispo para escribir sus propios documentos, aun cuando utilizasen los formularios diplomáticos específicos de una cancillería regia ${ }^{69}$.

Ahora bien, esto no quiere decir que el reinado de Alfonso VII el Emperador (11161157) no supusiera un despegue decisivo en la producción de documentos por la cancillería regia que coincide con un notable aumento del uso de la escritura en el conjunto de la sociedad. Frente a los escasos 41 documentos del reinado de Alfonso $\mathrm{V}$ de León apenas un siglo antes, se conservan hasta 676 documentos salidos de la cancillería de Alfonso VII ${ }^{70}$.

En efecto, durante su reinado asistimos a la consolidación definitiva y a un "claro desarrollo de una bien organizada y moderadamente activa cancillería regia» ${ }^{71}$. A partir de su reinado, según señala Nieto Soria, la cancillería real castellana sería durante siglos «el gran centro institucional consagrado a la creación y a la difusión más o menos sistemática de una retórica política», una labor llevada a cabo por clérigos del Rey que «se distinguieron como colaboradores de los monarcas en la celebración de actos y ceremonias de gran eficacia propagandística. Además, algunos de ellos escribieron obras destinadas a ofrecer una imagen muy idealizada de la persona regia ${ }^{72}$.

También vinculados al entorno áulico de Alfonso VII encontramos varios clérigos con el título de magister. Este título recibe Petrus Seguinis, canónigo compostelano, mencionado en un diploma regio del año 1142. Muchos años después, en 1190, un maestrescuela con el mismo nombre ejercía su labor en la escuela catedralicia de Sego$v^{7 a^{73}}$. O el arriba mencionado magister Hugo, canciller del Emperador y a quien encontramos trabajando en la cancillería real desde 1135 hasta $1165^{74}$.

En los años finales del reinado de Alfonso VII se intuye además la presencia de juristas romanistas en su cancillería o al menos eso ha deducido André Gouron del «tono justinianeo» de las fórmulas diplomáticas latinas entonces utilizadas, tales como la que aparece en un documento fechado en 1156: quod placuit excellentissime majestati domini imperatoris, de rancia prosapia imperial romana ${ }^{75}$. Similares fórmulas romanistas del tipo placuit aparecen en numerosos pasajes de la Chronica Adefonsi Imperatoris ${ }^{76}$, lo cual resulta doblemente significativo: porque esta fue terminada hacia 1147, es decir diez años antes del documento arriba mencionado y también por las vinculaciones curiales de su probable autor, Arnaldo de Astorga.

69 Linehan, History and the Historians, p. 234, n. 101.

70 Sierra Macarrón, «La escritura y el poder», pp. 255 y 258; cf. Lucas Álvarez, Manuel, "Las Cancillerías Reales (1109-1230)». En El reino de León en la Alta Edad Media, V. León: Centro de Estudios e Investigación San Isidoro, 1993, pp. 69-84.

71 Reilly, Bernard F. «The Chancery of Alfonso VII of León-Castilla: The Period 1116-1135 Reconsidered». Speculum, 1976, vol. 51/2, p. 261.

72 Nieto Soria, José Manuel. «Les clercs du Roi et les origines de l'État moderne en Castille: propagande et légitimation (xıIIème-Xvème siècles)». Journal of Medieval History, 1992, vol. 18, p. 299.

73 Iglesia Ferreirós, «Escuela, Estudio y maestros», pp. 314-315.

74 González, El Reino de Castilla, vol. 2, p. 176; Iglesia Ferreirós, "Escuela, Estudio y maestros», p. 316. También cabe mencionar la presencia en la curia de Alfonso VII del magister Juan, canciller desde 1149 del infante Sancho.

75 Gouron, "Aux origines de l'influence des glossateurs», pp. 345-346; Linehan, History and the Historians, p. 270

76 I, 16, 22, 66, 85, 91, 92; II, 35, 57 y 65 (LineHan, History and the Historians, p. 271, n. 12). 
MANUEL ALEJANDRO RODRÍGUEZ DE LA PEÑA

REALEZA SAPIENCIAL Y MECENAZGO CULTURAL EN LOS REINOS

DE LEÓN Y CASTILLA (IOOO-I 200)

La muerte de Alfonso VII no puso fin a estas políticas. Un documento del archivo de la catedral de Salamanca, datado en 1163, evidencia el envío de cuatro clerizones del capítulo catedralicio a Francia para estudiar allii ${ }^{77}$. Esta política de formación de clérigos ha sido vinculada con la figura del rey Fernando II de León (r. 1157-1188) ${ }^{78}$, quien, buscando «asesoramiento intelectual», habría llamado a su lado a sabios ultrapirenaicos como el magister aquitano Randulfo de Saintes ${ }^{79}$.

Se ha sugerido que pudo haber sido el propio Randulfo el que sugiriera la idea de enviar a los cuatro clerizones a estudiar allende los Pirineos. En esta dirección, también se ha puesto en valor el papel del obispo de Salamanca y canciller del Reino leonés, Pedro Suárez de Deza (ep. 1166-1173), o el de su sucesor en la cancillería, que compaginó sus labores de notario real con la de maestrescuela en la escuela catedralicia de Compostela (1164-1171). Sea como fuere, Salamanca estaba entonces dando sus primeros pasos para convertirse en el centro intelectual de primer orden que sería a principios del siglo xiII. Del mismo modo que Alfonso IX desempeñaría un papel decisivo en la fundación de la Universidad en el año 1218, su progenitor Fernando II aparece relacionado con los primeros pasos del capítulo catedralicio en la esfera educativa.

Parece razonable asumir que la presencia en la década de 1180 en la corte castellana, primero como canciller del rey (1178-1182) y luego también como arzobispo toledano (desde 1180), de un gran personaje de la talla intelectual de Pere de Cardona, erudito jurista romanista catalán y magister en Montpellier ${ }^{80}$ que acabaría alcanzando el capelo cardenalicio (diciembre, 1181) ${ }^{81}$, no dejó de tener sus repercusiones en el plano ideológico y cultural ${ }^{82}$. Si bien estas están todavía por determinarse, no es descartable que fuera él quien sugiriera a Alfonso VIII la captación de juristas de Italia y Francia para el studium generale de Palencia ${ }^{83}$.

Con todo, no deja de resultar desconcertante que el topos romanista de la maiestas regia desaparezca de la documentación de cancillería precisamente con su llegada a esta ${ }^{84}$. Cabe preguntarse si estamos acaso ante un sedicente partidario de la hierocracia. El que un adversario de las pretensiones del Sacro Imperio tan obstinado como Alejandro III le

77 GonzÁlez, Julio. «Notas sobre los orígenes de la Universidad de Salamanca». Boletín de la Biblioteca Menéndez y Pelayo, 1946, vol. 22, p. 47.

78 González, Julio. «Repoblación de la Extremadura leonesa». Hispania, 1943, vol. 3, pp. 212-218; WRIGHT, Roger. El Tratado de Cabreros (1206): Estudio sociofilológico de una reforma ortográfica. London: Queen Mary and Westfield College, 2000, p. 24.

79 Fletcher, Richard. "Notes on the Early History of the Cult of St Thomas Becket in Western Spain». En Bonilla Hernández, José Antonio (coord.). Salamanca y su proyección en el mundo: estudios históricos en honor de D. Florencio Marcos. Salamanca: [s. n.], 1992, p. 494; WRIGHT, El Tratado de Cabreros, p. 24.

80 Docencia que compatibilizaría con su puesto de canciller castellano, aunque Montpellier se encontrara a más de $500 \mathrm{~km}$ de la corte castellana (LineHAN, History and the Historians, p. 305).

81 Como cardenal-presbítero de San Lorenzo in Damaso. Buen conocedor de la lengua griega, emparentado con los condes de Barcelona, había sido discípulo del Placentino, el principal magister de Montpellier. Cf. Gouron, «Aux origines del'influence des glossateurs», p. 341; y «Autour de Placentin à Montpellier: maître Gui et Pierre de Cardona». Studia Gratiana, 1976, vol. 19, p. 337.

82 Linehan, Peter. Spain, 1157-1300. A Partible Inheritance. Oxford: Blackwell, 2011, p. 48.

83 Linehan, History and the Historians, p. 308.

84 Linehan, History and the Historians, pp. 306-307. 
hiciera cardenal a pesar de su perfil de clérigo áulico de un monarca tan autoritario como Alfonso VIII puede tener algo que ver con este hecho.

Durante el reinado de Alfonso VIII al canciller le auxiliará en sus tareas un único notarius que le sustituye en su ausencia y que a su vez está asistido por un grupo de escribanos (scriptores), que eran quienes realizaban las tareas materiales de trazado, escritura y dibujo de los diplomas ${ }^{85}$. Los estudiosos coinciden en señalar la mejor calidad del latín cancilleresco del reinado de Alfonso VIII en relación a la época anterior ${ }^{86}$.

Y es que parece que los notarios reales de Alfonso VIII solían tener un cierto bagaje cultural y en ocasiones ostentaban incluso el título de magister. Al menos tres magistri trabajaron en la cancillería como notarios reales durante el periodo como canciller del arzobispo de Toledo, Gonzalo Pérez (1183-1191): el maestro Mica, que parece ser el principal, y otros dos maestros llamados Miguel y Aimerico ${ }^{87}$. Pero ya en el periodo anterior encontramos en la cancillería a los magistri Juan (notario entre 1176 y 1181) y Gerardo (arcediano de Palencia; notario real entre 1178 y 1184$)^{88}$. Ahora bien, el maestro Mica sería el último notario real en ostentar el título de magister en la cancillería castellana ${ }^{89}$, con lo que terminaría lo que Aquilino Iglesia ha denominado «el auge de magistri entre los notarios regios» vivido a finales del siglo XII ${ }^{90}$.

Otros clérigos áulicos que acudieron a la llamada de Alfonso VIII fueron los italianos Arderico de Milán, magister en el malogrado studium de Uclés y luego promovido a la mitra de Sigüenza $(1178)^{91}$, o el ya mencionado Hugolino de Sesso. No menos brillante que los anteriores era Diego García de Campos, canciller de Castilla (1192-1217), autor del enciclopédico tratado latino Planeta y, sin duda, uno de los clérigos áulicos más interesantes y eruditos del largo reinado de Alfonso VIII. Diego García, formado en París, fue el protagonista indiscutible (aunque quizá renuente ${ }^{92}$ ) de la efímera pero significativa introducción de la lengua vernácula en los documentos de la cancillería regia entre 1206 y $1207^{93}$.

85 Martínez Díez, Gonzalo. Alfonso VIII, rey de Castilla y de Toledo (1158-1214). Gijón: Trea, 1995, p. 226; cf. Millares Carlo, Agustín. «La cancillería real de León y Castilla hasta fines del reinado de Fernando III». Anuario de Historia del Derecho Español, 1926, vol. 3, pp. 269-282.

86 Pérez González, Maurilio. El latín de la cancillería castellana (1158-1214). Salamanca: Ediciones Universidad de Salamanca, 1985, pp. 251-255.

87 Wright, El Tratado de Cabreros, pp. 29-30; Iglesia Ferreirós, «Escuela, Estudio y maestros», p. 316; GonzÁlez, El Reino de Castilla, vol. III, p. 932.

88 Iglesia Ferreirós, «Escuela, Estudio y maestros», p. 316; GonzÁlez, El Reino de Castilla, vol. 2, pp. 254 y 427 y vol. 3, pp. 921 y 927.

${ }^{89}$ Iglesia Ferreirós, «Escuela, Estudio y maestros», p. 316, n. 26.

90 Iglesia Ferreirós, «Escuela, Estudio y maestros», p. 318.

91 Maffer, «Fra Cremona, Montpellier e Palencia», pp. 18-19; Linehan, History and the Historians, p. 309.

92 Roger Wright apunta al arzobispo toledano Martín López de Pisuerga, gran canciller del reino, como el verdadero impulsor de la reforma, siendo el canciller Diego García, amante del latín clásico (como demuestra su Planeta), el poco entusiasta ejecutor de esta (El Tratado de Cabreros, p. 101).

93 Wright, Roger. Late Latin and Early Romance in Spain and Carolingian France. Liverpool: Cairns, 1982, p. 238 y El Tratado de Cabreros, p. 31; Linehan, History and the Historians, p. 320; cf. PÉrez GonzÁLEZ, Maurilio. "Los primeros documentos cancillerescos en castellano y su dependencia latina». En SANTOYO, Julio-César (ed.). «Fidus interpres»: Actas de las Primeras Jornadas Nacionales de Historia de la Traducción. León: Universidad de León, 1989, pp. 83-90. Esta nueva forma vernácula fue abandonada por razones no del todo 
MANUEL ALEJANDRO RODRÍGUEZ DE LA PEÑA

REALEZA SAPIENCIAL Y MECENAZGO CULTURAL EN LOS REINOS

DE LEÓN Y CASTILLA (IOOO-I 200)

En lo que toca al Studium palentino, tan ligado al monarca castellano, en el periodo anterior a la reforma de 1208 por parte del obispo Tello Téllez se atestigua documentalmente la presencia en el seno del capítulo de Palencia de al menos ocho magistri, la mayoría franceses e italianos a juzgar por sus nombres ${ }^{94}$. Parece que la mayor parte de estos magistri llegaron a Palencia antes de la fundación regia del Studium, con lo que la documentación contradiría el relato de Jiménez de Rada en su De Rebus Hispaniae sobre la convocatoria masiva por parte del monarca de una multitud de sapientes ultrapirenaicos:

Hizo buscar a los sabios de las Galias e Italia para que el culto del saber nunca faltara en su Reino, y reunió en Palencia a los maestros de todas las materias (omnium facultatum), a los que concedió amplias remuneraciones (magna stipendia) para que la sabiduría de cualquier materia fluyera como el maná ${ }^{95}$.

En realidad, todo apunta a que habría habido ya una «relativa abundancia» de magistri en la schola episcopal palentina antes de la institución del Studium generale ${ }^{96}$, pero en cualquier caso esto no obsta para que la acción regia fuera decisiva en la configuración de la primera Universidad de fundación regia del Occidente europeo ${ }^{97}$. Ello sobre todo si tenemos en cuenta la atrevida pero sugerente hipótesis de Adeline Rucquoi, quien ha sugerido que el Studium palentino en su primera etapa acaso no fuera más que simple y llanamente la «prolongación» o «ampliación» de la propia schola palatina

claras y no sería retomada hasta 1217. Ahora bien, Wright ha aportado una convincente hipótesis que lo explicaría, vinculando el abandono de la apuesta por el romance a la repentina muerte de Martín López de Pisuerga en 1208, lo que habría abortado la reforma. Rodrigo Jiménez de Rada, el nuevo arzobispo y canciller del reino, habría apostado por volver al latín, contando para ello con el apoyo de Diego García, formado en París como el prelado navarro (El Tratado de Cabreros, p. 101).

94 Iglesia Ferreirós, «Escuela, Estudio y maestros», pp. 317-322; Martínez Díez, Gonzalo. «La Universidad de Palencia. Revisión crítica». En Actas del II Congreso de Historia de Palencia. Palencia: Diputación Provincial de Palencia, 1990, vol. 4, pp. 156-157; y RucQuoI, Adeline. «Las dos vidas de la Universidad de Palencia (c. 1180-c. 1250)». En RucQuor, Rex, sapientia, nobilitas, p. 93. Uno de estos magistri, el italiano Lanfranco, puede ser la misma persona que el magister Lanfranco de Milán que en esos años actuó como embajador del rey de Portugal y luego del propio Alfonso VIII.

95 Jiménez de Rada, Rodrigo. De Rebus Hispaniae, VII, 34, ed. J. Fernández Valverde, Historia de los Hechos de España. Madrid: Alianza, 1989, p. 302; RucQuoI, "Alfonso VIII de Castilla y la Realeza», p. 62.

96 Martínez Díez, «La Universidad de Palencia», p. 157. Este autor contrasta el número de maestros en Palencia con los tres únicos atestiguados para todo el reino entre 1185 y 1208: el ya mencionado maestrescuela Pedro Seguini de Segovia y los maestros Menendo y Odas en Burgos. Ahora bien, Aquilino Iglesia («Escuela, Estudio y maestros», pp. 323-324) ha contradicho estas cifras y encontrado en los obituarios de Burgos los nombres de al menos otros maestros ligados a la catedral antes de 1208: Jaceus ( $†$ 1119), Adam ( $\dagger$ 1139), Guido ( $† 1165)$, Antecedens ( $† 1172)$, Bernardo ( $† 1177)$, Egidio $(† 1188)$ y Ricardo $(\dagger 1196)$. Para el año 1209 ambos investigadores coinciden en aceptar la presencia simultánea de al menos cuatro magistri en el cabildo burgalense; para otros ejemplos de magistri en el siglo XII en Toledo, Segovia, León y Oviedo, cf. RucquoI, «Éducation et société dans la Péninsule Ibérique», pp. 3-26.

97 Linehan, Spain, 1157-1300, p. 48; cf. Rodríguez de la PeÑa, Manuel Alejandro. «Rex institutor scholarum: la dimensión sapiencial de la Realeza en la cronística de León-Castilla y los orígenes de la Universidad de Palencia». Hispania Sacra, 2010, vol. 64, pp. 491-512. 
de Alfonso VIII ${ }^{98}$, una escuela de palacio al estilo carolingio-otónida cuya existencia previa aún no se ha demostrado de forma concluyente ${ }^{99}$.

Lo cierto es que a partir de la reforma de Tello Téllez nos encontramos con un mayor número de magistri en la documentación. De esta forma, entre 1210 y 1220 encontramos los nombres de Fornarius, Guillermo de Maranac, Miguel, Enrique, Lope, Aprilis, e incluso un laico llamado Roberto (c 1217) ${ }^{100}$, quizá el primer maestrescuela seglar del que haya evidencia documental en la Castilla medieval.

Contra lo que sostuvo nuestra historiografía durante años, desechando los testimonios concluyentes y concordantes del Tudense y el Toledano, hoy en día parece haber una cierta unanimidad entre los investigadores en torno a que la Universidad de Palencia tuvo una "doble vida", habiendo funcionado como studium durante un corto periodo antes de su refundación por parte del obispo Tello Téllez de Meneses entre 1208 y 1214. Las tres lecciones que se han conservado del maestro Ugolino de Sesso, supuestamente impartidas hacia 1196, la probable presencia allí de un joven Domingo de Guzmán hacia 1184 y otros indicios apuntan a que en torno al año 1180 se puso en funcionamiento en la ciudad de Palencia el primer studium generale hispánico ${ }^{101}$.

Todo esto es bien sabido. Pero queda aún por dilucidar el papel de Alfonso VIII en este episodio fundamental de la historia cultural española. Gonzalo Martínez Díez concede al obispo Raimundo de Palencia (1148-1183) un protagonismo en la iniciativa fundacional muy similar al que el propio don Tello tendría en la refundación años más tarde, si bien pondera el más que probable apoyo regio ${ }^{102}$.

Ciertamente, a la luz del perfil biográfico de Alfonso VIII, resulta extraño creer que el Rey Noble abrigara tal género de inquietudes intelectuales como para que de su mente partiera la iniciativa de fundar un studium generale, lo cual, de ser cierto, le convertiría en el primer soberano europeo en dar ese paso, casi cuarenta años antes de que Federico II de Sicilia fundara la Universidad de Nápoles y unos veinte años antes de que Felipe Augusto de Francia concediera su carta de privilegios a la Universidad de París. La profesora Rucquoi acepta esta última opción que da la razón a Jiménez de Rada varios siglos después.

A la hipótesis que concede al obispo don Raimundo la iniciativa exclusiva de la fundación, Adeline Rucquoi responde que no hay testimonio alguno de que el prelado

98 RucQuoI, «Las dos vidas de la Universidad de Palencia», pp. 97-98 y «Alfonso VIII de Castilla y la Realeza», p. 57.

99 La evidencia documental presentada en este sentido por Rucquoi, un documento equívoco de Alfonso VI de 1089 y otro que aún lo es más de Fernando II de 1183 («Las dos vidas de la Universidad de Palencia», p. 97, n. 25), dista de dejar zanjada la cuestión, ya que ambos son interpretables y además no prueban la existencia de una schola en la corte de Alfonso VIII. Rucquoi aportaría más datos sobre actividad docente en la corte leonesa en el siglo XI en otro artículo, pero en todo caso cien ańos antes del momento fundacional palentino: «El deber de saber. La tradición docente en la Edad Media castellana». En Mazín Gómez, Óscar (ed.). México en el mundo hispánico. Zamora, Mich: El Colegio de Michoacán, 2000, pp. 309-330.

100 Iglesia Ferreirós, «Escuela, Estudio y maestros», p. 319.

101 RucQuoi, Adeline. «Las rutas del saber. España en el siglo Xiı». Cuadernos de Historia de España, 1998-1999, vol. 75, pp. 56-57; vid. Martínez Díez, Gonzalo. «Tres lecciones del siglo XII del Estudio General de Palencia». Anuario de Historia del Derecho Español, 1991, vol. 60, pp. 391-404.

102 Martínez Díez, Gonzalo. Alfonso VIII. Burgos, 1995, p. 285. 
MANUEL ALEJANDRO RODRÍGUEZ DE LA PEÑA

REALEZA SAPIENCIAL Y MECENAZGO CULTURAL EN LOS REINOS

DE LEÓN Y CASTILLA (IOOO-I 200)

palentino tuviera inquietudes intelectuales. Por eso duda de que la iniciativa partiera de él. Descartada la posibilidad de que fuera una ampliación de la schola catedralicia y una hipotética asociación espontánea de magistri venidos de varios países, solo quedaría la de la iniciativa regia y la ampliación de la schola palatina, sostiene la investigadora francesa ${ }^{103}$.

El punto débil de esta teoría radica en la dificultad de demostrar la existencia de una schola palatina en tiempos de Alfonso VIII. Nos interesa principalmente ahora el discurso historiográfico que el Toledano y el Tudense desplegaron con ocasión de la fundación del studium palentino, un discurso lleno de matices ideológicos y de imágenes políticas de gran interés.

Para empezar, el arzobispo Rodrigo Jiménez de Rada no se limitó a establecer de forma contundente la fundación regia del studium palentino en un capítulo de su De Rebus Hispaniae intitulado De Institutione scholarum. Da a este acto una dimensión más propia de la teología política que de una "política educacional», con apelaciones a la inspiración del Espíritu Santo y al maná de la Sabiduría:

Y para que el ramillete de sus obras de caridad, que recayeron sobre él por obra del Espíritu Santo, no careciera de flor alguna, hizo buscar a los sabios de las Galias e Italia para que el culto del saber nunca faltara en su Reino, y reunió en Palencia a los maestros de todas las materias, a los que concedió amplias remuneraciones para que la sabiduría de cualquier materia fluyera como el maná en la boca de todo el que deseara aprender. Y aunque estos estudios sufrieron alguna interrupción, todavía subsisten por la gracia de Dios ${ }^{104}$.

El protagonismo del Rey Noble en el relato es total, ya que no aparece ningún otro actor, ni episcopal de ningún tipo. Los estipendios a los magistri palentinos se sitúan entre las obras de caridad de Alfonso VIII, ya que, de hecho, en este capítulo 34 del libro VII también se relata la construcción del hospital de Las Huelgas Reales en la ciudad de Burgos. Esto resulta muy significativo dentro de la concepción tesaurizadora del conocimiento a la que antes aludíamos.

Además de la convocatoria de estos clérigos áulicos de perfil universitario, el cosmopolitismo de la corte de Alfonso VIII también se debió a la afluencia de trovadores provenzales de cuya compañía el monarca gustaba y por quienes fue alabado como el pus savi rei. Entre ellos se contaron algunos de los trovadores más célebres de su tiempo, tales como Bertrán de Born, Foulques de Marsella, Giraldo de Calansó, Guevaudán, Pedro Vidal y Aimerico de Pegulhá ${ }^{105}$. Con todo, como ha seńalado Amaia Arizaleta en un reciente estudio, lo realmente relevante es el papel decisivo de los clérigos de la cancillería en la configuración ideológica y administrativa de la monarquía de Alfonso VIII:

En la década de 1170, la cancillería castellana comenzó a reiterar en sus documentos

la imagen de un Rey heroico [...]. Entre 1206 y 1207, parece que textos importantes vieron la

103 RucQuoI, «Las dos vidas de la Universidad de Palencia», pp. 728-730.

104 JimÉnez de RAdA, De Rebus Hispaniae, VII, 34, ed. J. Fernández Valverde, Historia de los Hechos de España, p. 302.

105 Milà y Fontanals, Manuel. De los trovadores en España. Barcelona: Instituto Miguel de Cervantes, 1966, pp. 70-83 y 112-126; RucQuoI, «Alfonso VIII de Castilla y la Realeza», p. 67. 


\author{
MANUEL ALEJANDRO RODRÍGUEZ DE LA PEŃA \\ REALEZA SAPIENCIAL Y MECENAZGO CULTURAL EN LOS REINOS \\ DE LEÓN Y CASTILLA (IOOO-I 200)
}

luz en espacios próximos a la cancillería real: el Poema de Benevívere, el tratado de Cabreros, puede que el Cantar de Mio Cid [...]. Estos textos e imágenes están a menudo relacionados con Alfonso VIII de Castilla. Este soberano explotó mejor que otros las posibilidades de lo escrito y se rodeó de clérigos que le podían ayudar en su ambición de presentarse como el primero de los monarcas de la Península Ibérica. La acción de los letrados de la cancillería creció en pujanza al mismo tiempo que el monarca aumentaba su poder ${ }^{106}$.

También Peter Linehan ha puesto en relación los acontecimientos de 1206-1207, entre los que destaca la utilización de la lengua vernácula en las actas de las cortes de Toledo ${ }^{107}$ y en la redacción del tratado de Cabreros con el reino de León, con la difusión de nuevos modelos ideológicos asociados a la llegada de magistri ultrapirenaicos a Palencia y el nacimiento del mester de clerecía ${ }^{108}$. Repárese en este sentido en que solo un año después, en 1208, el obispo Tello Téllez iniciaría la reforma del Studium de Palencia y le daría nuevos vuelos europeos como Studium generale con sanción pontificia.

Si bien el propósito del monarca al invitar a enseñar en Palencia a los scholares de Francia e Italia no fuera el proveer de un «tranquilo refugio» para los anónimos poetas del mester de clerecía, sino con toda probabilidad formar cuadros burocráticos para su cancillería, no por ello dejó de existir una cierta interrelación entre una monarquía castellana ahora «importadora de talento» y la brillante producción literaria asociada a los clérigos universitarios palentinos ${ }^{109}$.

En efecto, en los versos del mester de clerecía, muy en particular en ese espejo de príncipes con ropaje de relato épico llamado Libro de Alexandre, encontramos la máxima expresión del nuevo imaginario sapiencial de la Realeza feudal en Castilla ${ }^{110}$. Según ha señalado Arizaleta, el Libro de Alexandre fue una obra destinada al menos a dos contextos de recepción diferentes, en ocasiones superpuestos: el studium palentino y la corte de Alfonso VIII ${ }^{11}$.

Y es que, en realidad, la figura sapiencial de Alejandro Magno del Alexandre estuvo inspirada en un monarca castellano, sea en el propio Alfonso VIII como propone Arizaleta o en Fernando III como propuso Raymond Willis (lo que es improbable si atendemos a las últimas hipótesis sobre su datación ${ }^{112}$. Esta narrativa épica de una realeza sapiencial

106 Arizaleta, Amaia. Les clercs au palais. Chancellerie et écriture du pouvoir royal (Castille, 11571230). Paris: SEHM-Sorbonne, 2010, p. 277; LineHAN, Spain, 1157-1300, p. 48.

107 Cf. Hernández, Francisco J. «Las Cortes de Toledo de 1207». En Las Cortes de Castilla y León en la Edad Media. Valladolid: Cortes de Castilla y León, 1988, vol. 1, pp. 221-263.

108 Linehan, Spain, 1157-1300, pp. 48-49; cf. Rico, Francisco. «La clerecía del mester». Hispanic Review, 1985, vol. 53, pp. 1-23 y 127-150.

109 Linehan, Spain, 1157-1300, p. 48.

110 Arizaleta, Amaia. La translation d'Alexandre. Recherches sur les structures et les significations du "Libro de Alexandre». Paris: Klincksieck, 1999, pp. 240-259; cf. Rodríguez de la PeÑA, Manuel Alejandro. «La Realeza sapiencial y el ciclo del Alexandre medieval: tradición gnómica y arquetipos políticos en la literatura del Occidente latino (siglos XII y XIII)». Historia. Instituciones. Documentos, 1999, vol. 26, pp. 459-490.

111 Vid. Arizaleta, Amaia. "Alexandre en su Libro». La Corónica, 2000, vol. 28/2, pp. 3-20.

112 Willis, Raymond S. "Mester de clerecía. A definition of the Libro de Alexandre». Romance Philology, 1956, vol. 10, pp. 222-223. 
MANUEL ALEJANDRO RODRÍGUEZ DE LA PEÑA

REALEZA SAPIENCIAL Y MECENAZGO CULTURAL EN LOS REINOS

DE LEÓN Y CASTILLA (IOOO-I 2OO)

no puede desvincularse de las inquietudes intelectuales de su anónimo autor, un erudito amante de los clásicos y un hombre de universidad al fin y al cabo ${ }^{113}$.

Sea como fuere, en todo caso estaríamos ante lo que Arizaleta ha calificado de forma gráfica como écritures de clergie. De hecho, si aceptamos la interesante hipótesis de Isabel Uría, el Libro de Alexandre no sería sino un proyecto literario colectivo de un magister de la Universidad de Palencia y sus estudiantes ${ }^{114}$. Del mismo modo, Alan Deyermond sugirió en su día que el Auto de los Reyes Magos había sido concebido en la escuela catedralicia de Toledo ${ }^{115}$.

En esta dirección, Adeline Rucquoi ha vinculado la reflexión teológica realizada por «los letrados y clérigos» que rodeaban a los reyes de Castilla y Navarra en el siglo XII con el alumbramiento de un nuevo atributo del monarca: la sabiduría, «sino y señal de su papel como lugartenientes de Dios en la Tierra» ${ }^{16}$. En efecto, Rucquoi argumenta convincentemente que el modelo de optimus Rex que el entorno de Alfonso VIII puso en circulación estaba apoyado sobre todo en cuatro virtudes políticas: dos «antiguas», es decir, propias de la Realeza feudal de anteriores reinados, tales como la liberalitas (largueza) y la strenuitas (fortaleza militar); y dos «nuevas», más propias del cosmopolitismo del renacimiento del siglo xII: la curialitas (la palacianía del mester de clerecía) y la sapientia ${ }^{117}$. En realidad, como hemos visto anteriormente, estas dos virtudes políticas ya estaban en boga en el siglo $\mathrm{x}$ en la corte otónida, pero ciertamente no llegaron a imponerse en los reinos hispánicos hasta bien entrado el siglo XII.

En el caso de Alfonso VIII, Adeline Rucquoi ha visto un modelo feudal-sapiencial de Rex magister en los lazos de fidelidad que el rey de Castilla tenía con sus alumni, esto es, aquellos de sus vasallos que se educaron en su infancia en la curia regia. Esta investigadora llega a sugerir que la Universidad de Palencia no fue una evolución de la schola catedralicia ni una fundación ex novo, sino que habría sido producto del engrandecimiento de una presunta schola palatina preexistente, de cuya existencia, sin embargo, no tenemos sino indicios poco concluyentes.

113 Michael, Ian. The Treatment of Classical Material in the "Libro de Alexandre». Manchester: Manchester University Press, 1970, p. 86; Bermejo, José Luis. Máximas, principios y símbolos politicos (una aproximación histórica). Madrid: Centro de Estudios Constitucionales, 1986, p. 89; Rodríguez DE LA PeÑA, «La Realeza sapiencial y el ciclo del Alexandre», p. 464.

114 URÍA MAQUA, Isabel. Panorama crítico del «mester de clerecía». Madrid: Castalia, 2000, pp. 193-196.

115 Deyermond, Alan. «El Auto de los Reyes Magos y el renacimiento del siglo XII». En Actas del IX Congreso Internacional de la Asociación de Hispanistas. Frankfurt: Vervuert Verlag, 1986, p. 187.

116 Rucquor, Adeline. «De los reyes que no son taumaturgos: los fundamentos de la Realeza en España». En RucQuoI, Rex, sapientia, nobilitas, pp. 29-30.

117 RucquoI, «Alfonso VIII de Castilla y la Realeza», p. 49; ArIzaleta, Amaia y Jean-Marie, Stéphanie. «En el umbral de la santidad: Alfonso VIII de Castilla». En Arizaleta, Amaia et ál. (éds.). Pratiques hagiographiques dans l'Espagne du Moyen Âge et du Siècle d'Or. II. Toulouse: CNRS-Université de Toulouse-Le Mirail, 2007, p. 5; Rucquoi pone como ejemplo de la introducción del concepto de curialitas en Castilla un pasaje del Planeta, de Diego García de Campos, en el que este expone que actuar curialiter equivale a actuar sin rusticitas, esto es, con dignidad, gravedad, modestia, comedimiento y moderación (Planeta, ed. M. Alonso. Madrid, 1943, p. 164). Este pasaje en concreto recuerda vivamente similares admoniciones de los clérigos otónidas contra el comportamiento rústico o agreste en la corte (cf. JAEGER, Stephen. The Origins of Courtliness. Civilizing Trends and the Formation of Courtly Ideals (939-1210). Philadelphia: University of Pennsylvania Press, 1985, pp. 211-235). 


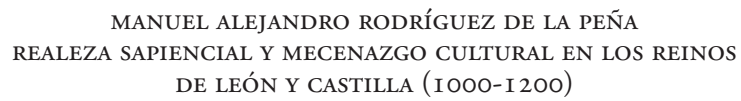

Sea como fuere, lo que realmente nos interesa aquí es el marco interpretativo de la Realeza sapiencial en el cual Rucquoi inserta sus teorías. De esta forma, sostiene que «el ideal del Rex sapiens, magister de su pueblo, que ha recibido de Dios más entendimiento que el resto de los hombres y que es responsable ante Él del grado de conocimiento de sus súbditos según dirá Alfonso X el Sabio, entró en escena en la segunda mitad del siglo XII en el seno de la corte real, microcosmos y macrocosmos de lo que será el conjunto del Reino» ${ }^{118}$.

Considero que esta es la clave interpretativa a la luz de la cual hay que examinar las motivaciones que llevaron a los soberanos de León y Castilla a iniciar los diferentes procesos de mecenazgo artístico y cultural que hemos analizado en este trabajo. El ideal sapiencial de la Realeza cristiana que estos monarcas intentaron encarnar resulta de cardinal importancia para comprender cabalmente el decisivo papel que jugaron en la historia cultural de estos siglos.

\section{ReFERENCIAS BibliográficAs}

Alfonso X. Primera Crónica General de España, ed. A. García Solalinde. Madrid: Centro de Estudios Históricos, 1930.

Arizaleta, Amaia y Jean-Marie, Stéphanie. «En el umbral de la santidad: Alfonso VIII de Castilla». En Arizaleta, Amaia et ál. (éds.). Pratiques hagiographiques dans l'Espagne du Moyen Âge et du Siècle d'Or. II. Toulouse: CNRS-Université de Toulouse-Le Mirail, 2007, p. 5.

Arizaleta, Amaia. «Alexandre en su Libro». La Corónica, 2000, vol. 28/2, pp. 3-20.

Arizaleta, Amaia. La translation d'Alexandre. Recherches sur les structures et les significations du "Libro de Alexandre». Paris: Klincksieck, 1999.

Arizaleta, Amaia. Les clercs au palais. Chancellerie et écriture du pouvoir royal (Castille, 11571230). Paris: SEHM-Sorbonne, 2010.

Barcala, Andrés. «Las universidades españolas durante la Edad Media». Anuario de Estudios Medievales, 1985, vol. 15, pp. 83-126.

Barrau-Dihigo, Louis. «Remarques sur la Chronique dite d'Alphonse III». Revue Hispanique, 1919, vol. 46, pp. 323-381.

Bermejo, José Luis. Máximas, principios y simbolos políticos (una aproximación histórica). Madrid: Centro de Estudios Constitucionales, 1986.

Bishko, Charles Julian. «The Liturgical Context of Fernando I's Last Days». Hispania Sacra, 1964, vol. 17 , pp. 33-45 y 47-49.

Boto Varela, Gerardo. «Las Dueñas de la memoria. San Isidoro de León y sus Infantas». Románico, 2010, vol. 10, p. 75.

Castiñeiras González, Manuel. «Algunos usos y funciones de la imagen en la miniatura hispánica del siglo Xı: los Libros de Horas de Fernando I y Sancha». En Congresso Peninsular de História da Arte. Propaganda \& poder. Lisboa: Colibrí, 2000, pp. 74-94.

Castiñeiras González, Manuel. «Libro de Horas de Fernando I y Sancha». En Valle Pérez, José Carlos (coord.). Enciclopedia del Románico en Galicia. A Coruña. Aguilar de Campoo: Fundación Santa María la Real, 2013, vol. 2, p. 1144.

118 Rucquor, Adeline. «La royauté sous Alphonse VIII de Castille». Cahiers de Linguistique Hispanique Médiévale, 2000, vol. 23/1, p. 222; vid. de la misma autora, «El Rey Sabio: cultura y poder en la Monarquía medieval castellana». En Repoblación y Reconquista. Actas del III Curso de Cultura medieval. Aguilar de Campoo: Centro de Estudios del Románico, 1993, pp. 77-87. 
MANUEL ALEJANDRO RODRÍGUEZ DE LA PEÑA

REALEZA SAPIENCIAL Y MECENAZGO CULTURAL EN LOS REINOS

DE LEÓN Y CASTILLA (IOOO-I 200)

Collins, Roger. «Literacy in Early Medieval Spain». En McKitterick, Rosamond (ed.). The Uses of Literacy in Early Medieval Europe. Cambridge: Cambridge University Press, 1990, p. 128.

Curtius, Ernst Robert. Literatura europea y Edad Media latina. México: Fondo de Cultura Económica, 1955.

Deyermond, Alan. «El Auto de los Reyes Magos y el renacimiento del siglo XII». En Actas del IX Congreso Internacional de la Asociación de Hispanistas. Frankfurt: Vervuert Verlag, 1986, p. 187.

DíAz y DíAz, Manuel C. «Problemas de algunos manuscritos hispánicos de las Etimologías de Isidoro de Sevilla». En Autenrieth, Johanne und BrunhölzL, Franz (eds.). Festschrift Bernhard Bischoff zu seinem 65. Geburtstag. Stuttgart: Anton Hiersemann, 1971, pp. 73-74.

DíAz y Díaz, Manuel C. Códices visigóticos en la monarquía leonesa. León: Centro de Estudios e Investigación San Isidoro, 1983.

DíAz y Díaz, Manuel C. Libros y librerías en La Rioja altomedieval. Logroño: Servicio de Cultura de la Excma. Diputación Provincial, 1979.

FÉRotin, Marius. «Deux manuscrits wisigothiques de la Bibliothèque de Ferdinand $\mathrm{I}^{\mathrm{er}}$. Bibliothèque de l'École des Chartes, 1901, vol. 62, pp. 374-387.

Fletcher, Richard. «Notes on the Early History of the Cult of St Thomas Becket in Western Spain». En Bonilla Hernández, José Antonio (coord.). Salamanca y su proyección en el mundo: estudios históricos en honor de D. Florencio Marcos. Salamanca: [s. n.], 1992, p. 494.

Fontaine, Jacques. Isidoro de Sevilla. Génesis y originalidad de la cultura hispánica en tiempos de los Visigodos. Madrid: Encuentro, 2002.

Galván Freile, Fernando. «El Liber Canticorum et Horarum de Sancha (B.G.U.S., MS. 2668): entre la tradición prerrománica y la modernidad». En Arbeiter, Achim et al. (ed.). Hispaniens norden im 11. Jahrhundert. Christliche Kunst im Umbruch. Petersberg: Imhof Verlag, 2009, pp. 248-256.

Gil de Zamora, Juan. De Preconiis Hispaniae, ed. lat. M. de Castro y Castro; ed. esp. Alabanza de España, José Luis Martín. Zamora: Ayuntamiento de Zamora, 1995.

Gómez-Moreno, Manuel. «El arca de las reliquias de San Isidoro de León». Archivo Español de Arte y Arqueología, 1932, vol. 7, pp. 205-212.

Gómez-Moreno, Manuel. «Las primeras crónicas de la Reconquista». Boletín de la Real Academia de la Historia, 1932, vol. 100, p. 586.

Gómez-Moreno, Manuel. En torno al crucifijo de los reyes Fernando y Sancha. Madrid: Instituto de Restauración, 1965.

Gómez-Moreno, Manuel. Iglesias mozárabes. Arte español de los siglos IX al XI. Madrid: Centro de Estudios Históricos, 1919.

GonzÁlez, Julio. «Notas sobre los orígenes de la Universidad de Salamanca». Boletín de la Biblioteca Menéndez y Pelayo, 1946, vol. 22, p. 47.

González, Julio. «Repoblación de la Extremadura leonesa». Hispania, 1943, vol. 3, pp. 212-218.

González, Julio. El reino de Castilla en la época de Alfonso VIII. Madrid: Escuela de Estudios Medievales, 1960.

Gouron, André. «Autour de Placentin à Montpellier: maître Gui et Pierre de Cardona». Studia Gratiana, 1976, vol. 19, p. 337.

Gouron, André. «Aux origines de l'influence des glossateurs en Espagne». Historia, Instituciones, Documentos, 1984, vol. 10, p. 325.

Havens Caldwell, Susan. «Urraca of Zamora and San Isidoro in León: Fulfilment of a Legacy». Woman's Art Journal, 1986, vol. 7/1, p. 21.

Henriet, Patrick. «L'Historia Silensis, chronique écrite par un moine de Sahagún. Nouveaux arguments».e-Spania, 2012, vol. 14. 


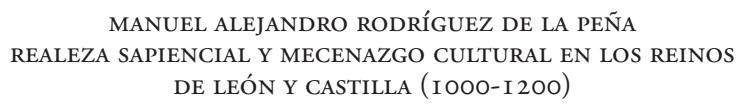

Henriet, Patrick. "Un exemple de religiosité politique: Saint Isidore et les rois de León $\left(\mathrm{XI}^{\mathrm{e}}-\mathrm{XIII}{ }^{\mathrm{e}}\right.$ siècles)». En Derwich, Marek y Dmitriev, Michel (eds.). Fonctions sociales et politiques $d u$ culte des saints dans les societés de rite grec et latin au Moyen Âge et à l'époque moderne. Approche comparative. Wrocław: Larhcor, 1999, pp. 77-93.

Hernández, Francisco J. «Las Cortes de Toledo de 1207». En Las Cortes de Castilla y León en la Edad Media. Valladolid: Cortes de Castilla y León, 1988, vol. 1, pp. 221-263.

Historia Silense, ed. Justo Pérez de Urbel y Atilano González. Madrid: Consejo Superior de Investigaciones Científicas, 1959.

Iglesia Ferreirós, Aquilino. «Escuela, Estudio y maestros». Historia, Instituciones, Documentos, 1998, vol. 25, p. 313.

Iglesia FerReirós, Aquilino. «Rex superiorem non recognoscens: Hugolino de Sesso y el Studium de Palencia». Initium. Revista Catalana d'Història del Dret, 1998, vol. 3, pp. 1-205.

IsLa Frez, Amancio. Memoria, culto y monarquía hispánica entre los siglos X y XII. Jaén: Universidad de Jaén, 2007.

Jaeger, Stephen. The Origins of Courtliness. Civilizing Trends and the Formation of Courtly Ideals (939-1210). Philadelphia: University of Pennsylvania Press, 1985.

Jiménez de Rada, Rodrigo. De Rebus Hispaniae, VII, 34, ed. J. Fernández Valverde, Historia de los Hechos de España. Madrid: Alianza, 1989.

Karge, Henrik. «De la portada románica de la transfiguración al Pórtico de la Gloria. Nuevas investigaciones sobre la fachada occidental de la catedral de Santiago de Compostela». Boletín del Seminario de Estudios de Arte, 2009, vol. 75, p. 22.

Klaniczay, Gabor. "The Ambivalent Model of Solomon for Royal Sainthood and Royal Wisdom». En Biliarsky, Ivan et al. (ed.). The Biblical Models of Power and Law: Papers of the International Conference. Frankfurt: Peter Lang GmbH, 2008, p. 77.

KLINKA, Emmanuelle. «Ego misera et peccatrix...: El Liber mozarabicus canticorum et horarum (Salamanca, ms. 2668)».e-Spania, 2012, vol. 13.

KuINKA, Emmanuelle. «Sancha, infanta y reina de León». e-Spania, 2008, vol. 5.

Kume, Junko. «Transmisión y enriquecimiento de programas iconográficos en la Alta Edad Media: el caso de las Etimologías de doña Sancha de León». Actas del XVII Congreso Nacional de Historia del Arte, CEHA-2008, Art i memoria. Barcelona, 2008, en prensa.

Le Morvan, Gäel. «Reinos e imperio: la Historia legionensis (llamada silensis) y la reivindicación leonesa de la herencia visigótica». e-Spania, 2012, vol. 14.

Linehan, Peter. History and the Historians of Medieval Spain. Oxford: Clarendon Press, 1993.

Linehan, Peter. Spain, 1157-1300. A Partible Inheritance. Oxford: Blackwell, 2011.

Lucas Álvarez, Manuel, «Las Cancillerías Reales (1109-1230)». En El reino de León en la Alta Edad Media, V. León: Centro de Estudios e Investigación San Isidoro, 1993, pp. 69-84.

Maffei, Domenico. «Fra Cremona, Montpellier e Palencia nel secolo XII». Rivista Internazionale di Diritto Comune, 1990, vol. 1, pp. 9-30.

Martin, Georges. "La Historia legionensis (llamada silensis) como memoria identitaria de un reino y como autobiografía». e-Spania, 2012, vol. 14.

Martin, Thérèse. «Mujeres, hermanas e hijas: el mecenazgo femenino en la familia de Alfonso VI». Anales de Historia del Arte, 2011, vol. extraordinario 2, pp. 148-150.

Martin, Thérèse. Queen as King: Politics and Architectural Propaganda in Twelfth-Century Spain. Leiden: Brill, 2006.

Martínez Díez, Gonzalo. «La Universidad de Palencia. Revisión crítica». En Actas del II Congreso de Historia de Palencia. Palencia: Diputación Provincial de Palencia, 1990, vol. 4, pp. 156-157. 
MANUEL ALEJANDRO RODRÍGUEZ DE LA PEÑA

REALEZA SAPIENCIAL Y MECENAZGO CULTURAL EN LOS REINOS

DE LEÓN Y CASTILLA (IOOO-I 200)

Martínez DíEz, Gonzalo. «Tres lecciones del siglo XII del Estudio General de Palencia». Anuario de Historia del Derecho Español, 1991, vol. 60, pp. 391-404.

Martínez Díez, Gonzalo. Alfonso VIII, rey de Castilla y de Toledo (1158-1214). Gijón: Trea, 1995.

Martínez Díez, Gonzalo. Alfonso VIII. Burgos, 1995.

McKitterick, Rosamond. "Ottonian Intellectual Culture in the Tenth Century and the Role of Theophanu». Early Medieval Europe, 1993, vol. 2/1, pp. 55, 57, 59 y 62-63.

MenÉndez Pidal, Gonzalo. «Mozárabes y asturianos en la cultura de la Alta Edad Media (en relación especial con la historia de los conocimientos geográficos)». En Varia Medievalia. Madrid: Real Academia de la Historia, 2003, vol. I, p. 56.

Michael, Ian. The Treatment of Classical Material in the "Libro de Alexandre». Manchester: Manchester University Press, 1970.

Milà y Fontanals, Manuel. De los trovadores en España. Barcelona: Instituto Miguel de Cervantes, 1966.

Millares Carlo, Agustín. «La cancillería real de León y Castilla hasta fines del reinado de Fernando III». Anuario de Historia del Derecho Español, 1926, vol. 3, pp. 269-282.

Moralejo Álvarez, Serafín. "Ars sacra et sculpture romane monumentale: le trésor et le chantier de Compostelle». Les Cahiers de Saint-Michel de Cuxa, 1980, vol. 2, pp. 189-238.

Moralejo Álvarez, Serafín. "Notas a la ilustración del Libro de Horas de Fernando I». En Díaz y Díaz, Manuel C. Libro de Horas de Fernando I de León. Edición facsímile do manuscrito 609 (Res. 1) da Biblioteca Universitaria de Santiago de Compostela. Santiago de Compostela: Xunta de Galicia, 1995, pp. 53-63.

Nieto Soria, José Manuel. «Les clercs du Roi et les origines de l'État moderne en Castille: propagande et légitimation (xıIIème-Xvème siècles)». Journal of Medieval History, 1992, vol. 18, p. 299.

Pérez González, Maurilio. «Los primeros documentos cancillerescos en castellano y su dependencia latina». En SANToyo, Julio-César (ed.). «Fidus interpres»: Actas de las Primeras Jornadas Nacionales de Historia de la Traducción. León: Universidad de León, 1989, pp. 83-90.

Pérez GonzÁlez, Maurilio. El latín de la cancillería castellana (1158-1214). Salamanca: Ediciones Universidad de Salamanca, 1985.

Post, Gaines. «Roman Law and Early Representation in Spain and Italy, 1150-1250». Speculum, 1943, vol. 18/2, pp. 216-217.

Prelog, Jan. Die Chronik Alfons' III. Untersuchung und kritische Edition der vier Redaktionen. Frankfurt: Lang, 1980.

ReILly, Bernard F. «The Chancery of Alfonso VII of León-Castilla: The Period 1116-1135 Reconsidered». Speculum, 1976, vol. 51/2, p. 261.

Rico, Francisco. «La clerecía del mester». Hispanic Review, 1985, vol. 53, pp. 1-23 y 127-150.

Rodríguez de la PeÑA, Manuel Alejandro. «Ideología política y crónicas monásticas: la concepción cluniacense de la Realeza en la España del siglo XII». Anuario de Estudios Medievales, 2000, vol. 30/2, pp. 699-700.

Rodríguez de la Peña, Manuel Alejandro. «La Realeza sapiencial y el ciclo del Alexandre medieval: tradición gnómica y arquetipos políticos en la literatura del Occidente latino (siglos XII y XIII)». Historia. Instituciones. Documentos, 1999, vol. 26, pp. 459-490.

Rodríguez de la PeÑA, Manuel Alejandro. «Rex institutor scholarum: la dimensión sapiencial de la Realeza en la cronística de León-Castilla y los orígenes de la Universidad de Palencia». Hispania Sacra, 2010, vol. 64, pp. 491-512.

RucquoI, Adeline. «Alfonso VIII de Castilla y la Realeza». En Rucquor, Adeline. Rex, Sapientia, Nobilitas. Estudios sobre la Peninsula Ibérica medieval. Granada: Editorial Universidad de Granada, 2006, p. 54. 
Rucquoi, Adeline. «Contribution des studia generalia à la pensée hispanique médiévale». En Soto Rábanos, José María (coord.). Pensamiento medieval hispano: homenaje a Horacio Santiago Otero. Madrid: Consejo Superior de Investigaciones Científicas, 1998, pp. 739-740.

RucQuoI, Adeline. «De los reyes que no son taumaturgos: los fundamentos de la Realeza en España». En Rucquor, Adeline. Rex, Sapientia, Nobilitas. Estudios sobre la Peninsula Ibérica medieval. Granada: Editorial Universidad de Granada, 2006, pp. 29-30.

Rucquor, Adeline. «Éducation et société dans la Péninsule Ibérique médiévale». Histoire de l'Éducation, 1996, vol. 69, p. 9.

RuCQuoI, Adeline. «El deber de saber. La tradición docente en la Edad Media castellana». En Mazín Gómez, Óscar (ed.). México en el mundo hispánico. Zamora, Mich: El Colegio de Michoacán, 2000, pp. 309-330.

Rucquoi, Adeline. «El Rey Sabio: cultura y poder en la Monarquía medieval castellana». En Repoblación y Reconquista. Actas del III Curso de Cultura medieval. Aguilar de Campoo: Centro de Estudios del Románico, 1993, pp. 77-87.

RucquoI, Adeline. «La royauté sous Alphonse VIII de Castille». Cahiers de Linguistique Hispanique Médiévale, 2000, vol. 23/1, p. 222.

RucQuor, Adeline. «Las dos vidas de la Universidad de Palencia (c. 1180-c. 1250)». En RucQuoI, Adeline. Rex, Sapientia, Nobilitas. Estudios sobre la Peninsula Ibérica medieval. Granada: Editorial Universidad de Granada, 2006, p. 93.

RucquoI, Adeline. "Las rutas del saber. España en el siglo XII». Cuadernos de Historia de España, 1998-1999, vol. 75, pp. 56-57.

Ruiz de la Peña, Juan Ignacio. Crónicas asturianas, estudio preliminar. Oviedo: Servicio de Publicaciones, Universidad de Oviedo, 1985.

Ruiz García, Elisa. «Arma regis: Los libros de Fernando I y doña Sancha (1035-1065)». En Los reyes bibliófilos, ed. A. B. Sánchez Prieto, Madrid, en prensa.

SÁenz-López Pérez, Sandra. «El mundo para una reina: los mappaemundi de Sancha de León (1013-1067)». Anales de Historia del Arte, 2010, vol. extraordinario 2, p. 319.

Sánchez-Albornoz, Claudio. Orígenes de la Nación española. El Reino de Asturias. Estudios críticos sobre la Historia del Reino de Asturias. Oviedo: Instituto de Estudios Asturianos, 1972-1975.

Schмidt, Paul Gerhard. «Heinrich III. Das Bild des Herrschers in der Literatur seiner Zeit». Deutsches Archiv, 1983, vol. 39, pp. 582-590.

Sierra Macarrón, Leonor. «La escritura y el poder. El aumento de la producción escrita en Castilla y León (siglos XI-XIII)». Signo, 2001, vol. 8, p. 255.

Steger, Hugo. David rex et Propheta. König David als Vorbildlicher Verkörperung des Herrschers und Dichters im Mittelalter, nach Bilddarstellungen des achten bis zwölften Jahrhunderts. Nürnberg: Verlag Hans Carl, 1961.

Uría MaQua, Isabel. Panorama crítico del «mester de clerecía». Madrid: Castalia, 2000.

WALKer, Rose. "Becoming Alfonso VI: the king, his sister and the arca santa reliquary». Anales de Historia del Arte, 2011, vol. extraordinario 2, p. 396.

Weinfurter, Stefan. The Salian Century. Main currents in an Age of transition. Philadelphia: University Pennsylvania Press, 1999.

Werckmeister, Karl. «The First Romanesque Beatus Manuscripts and the Liturgy of Death». En Actas del Simposio para el estudio de los códices del Comentario al Apocalipsis de Beato de Liébana. Madrid: Joyas Bibliográficas, 1978-1980, vol. 1, pp. 167-192.

Williams, John. «Fernando I and Alfonso VI as Patrons of the Arts». Anales de Historia del Arte, 2011, vol. extraordinario 2, p. 413. 


\author{
MANUEL ALEJANDRO RODRÍGUEZ DE LA PEŃA \\ REALEZA SAPIENCIAL Y MECENAZGO CULTURAL EN LOS REINOS \\ DE LEÓN Y CASTILLA (IOOO-I 200)
}

Williams, John. «León: The Iconography of a Capital». En Bisson, Thomas N. (ed.). Cultures of Power. Lordship, Status, and Process in Twelfth-Century Europe. Philadelphia: University of Pennsylvania Press, 1995, p. 237.

Willis, Raymond S. "Mester de clerecía. A definition of the Libro de Alexandre». Romance Philology, 1956, vol. 10, pp. 222-223.

WRIGHT, Roger. "Textos asturianos de los siglos IX y x. Latín bárbaro o romance escrito». Lletres Asturianes, 1991, vol. 41, p. 23.

Wright, Roger. El Tratado de Cabreros (1206): Estudio sociofilológico de una reforma ortográfica. London: Queen Mary and Westfield College, 2000.

Wright, Roger. Late Latin and Early Romance in Spain and Carolingian France. Liverpool: Cairns, 1982.

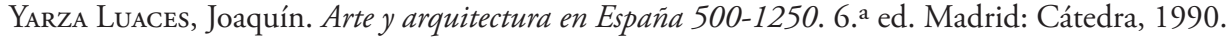

